Int. J. Dev. Biol. 51: 557-570 (2007)

doi: $10.1387 / \mathrm{ijdb} .072373 \mathrm{hs}$

\title{
A network of growth and transcription factors controls neuronal differentation and survival in the developing ear
}

\author{
HORTENSIA SÁNCHEZ-CALDERÓN"1, MARTA MILO², YOLANDA LEÓN ${ }^{1,3}$ and ISABEL VARELA-NIETO*,1 \\ 'Instituto de Investigaciones Biomédicas "Alberto Sols", CSIC-UAM, Madrid, Spain, 2Department of Biomedical Science, University of \\ Sheffield, U.K. and ${ }^{3}$ Departamento de Biología, Unidad de Fisiología Animal, Universidad Autónoma de Madrid, Spain
}

\begin{abstract}
Inner ear neurons develop from the otic placode and connect hair cells with central neurons in auditory brain stem nuclei. Otic neurogenesis is a developmental process which can be separated into different cellular states that are characterized by a distinct combination of molecular markers. Neurogenesis is highly regulated by a network of extrinsic and intrinsic factors, whose participation in auditory neurogenesis is discussed. Trophic factors include the fibroblast growth factor, neurotrophins and insulin-like peptide families. The expression domains of transcription factor families and their roles in the regulation of intracellular signaling pathways associated with neurogenesis are also discussed. Understanding and defining the key factors and gene networks in the development and function of the inner ear represents an important step towards defeating deafness.
\end{abstract}

KEY WORDS: otic neurogenesis, IGF-I, FGF, inner ear, auditory ganglion, cochlear microarray

\section{Otic neurogenesis}

The inner ear develops from the otic placode, an ectodermal patch located close to the neural tube that invaginates to form a transitory structure, the otic cup. This cup subsequently closes and pinches off from the ectoderm to generate the otic vesicle (Figure 1). The otic vesicle is an autonomous structure that contains the information required to generate most of the cell types and structures of the adult inner ear (Bissonnette and Fekete, 1996; Bever et al., 2003; reviewed in Varela-Nieto et al., 2004). The mammalian inner ear is composed of six distinct sensory organs: the three cristae of the semicircular canal, the two maculae of the saccule and utricle and the organ of Corti in the cochlea. The cristae and the maculae are vestibular organs, whereas the organ of Corti is the organ of hearing (reviewed in Moller, 2006). The inner ear cochlear ganglion is formed by bipolar neurons that connect the peripheral sensory receptors or hair cells with central neurons in auditory brain stem nuclei. The correct organogenesis of the inner ear involves a dynamic balance of cell proliferation, differentiation, survival and death, processes that are tightly regulated by a network of extrinsic and intrinsic factors (Frago et al., 2000; Varela-Nieto et al., 2003 and 2004; Leon et al., 2004).

The process of otic neurogenesis can be separated into different cellular states, each characterized by a distinct combination of molecular markers (summarized in Figure 1A). The first visible output of otic neurogenesis is the delamination of neural cells (otic neuroblasts) from the otic cup (Fig. 1B). These neuroblasts are committed to generate otic neurons and they populate the cochleo-vestibular ganglion (CVG). This ganglion is generated from a region of the otic vesicle epithelium denominated the prospective neural-sensorial domain and that is defined by the domain in which $\mathrm{Ngn1}$ and Deltal1 are co-expressed at early stages (Adam et al., 1998; Abu-Elmagd et al., 2001). It is believed that both neurons and sensory cells derive from a common multipotent progenitor cell (MPe, in Figure 1A) (Brigande et al., 2000; Lang and Fekete, 2001). Indeed, there is a loss of ganglion neurons and a decrease in the number of hair cells in the mouse Ngn1 null-mutant (Ma et al., 2000). Interestingly, Notch and its ligands Delta 1, Serrate 1 and Serrate2(Serin the chicken, Jagin the mouse) are expressed in the otic placode (Adam et al., 1998; Eddison et al., 2000; Cole et al., 2000). While Ser1 is expressed at the anterior and posterior poles of the otic cup, Ser2 overlaps with the neural sensory domain defined by Delta1 (Lang and Fekete, 2001). The Delta-Notch pathway is again essential at later steps when the cell fate decision of becoming a hair cell or a supporting cell is taken (Lanford et al., 1999; Lang and Fekete,

Abbreviations used in this paper: BDNF, brain-derived neurotrophic factor; bHLH, basic helix-loop-helix; CVG, cochleovestibular ganglion; FGF, fibroblast growth factor; IGF, insulin-like growth factor; NGF, nerve growth factor; NT, neurotrophin.


Spain. Fax: +34-91-585-4401. e-mail: ivarela@iib.uam.es
} 
A

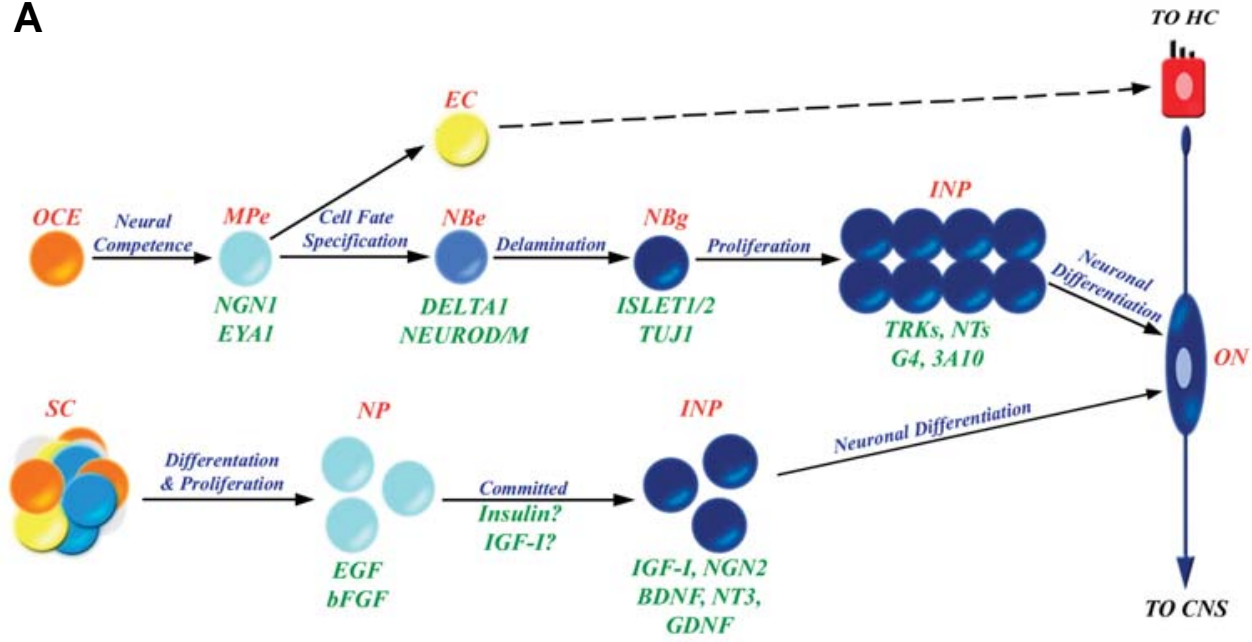

B
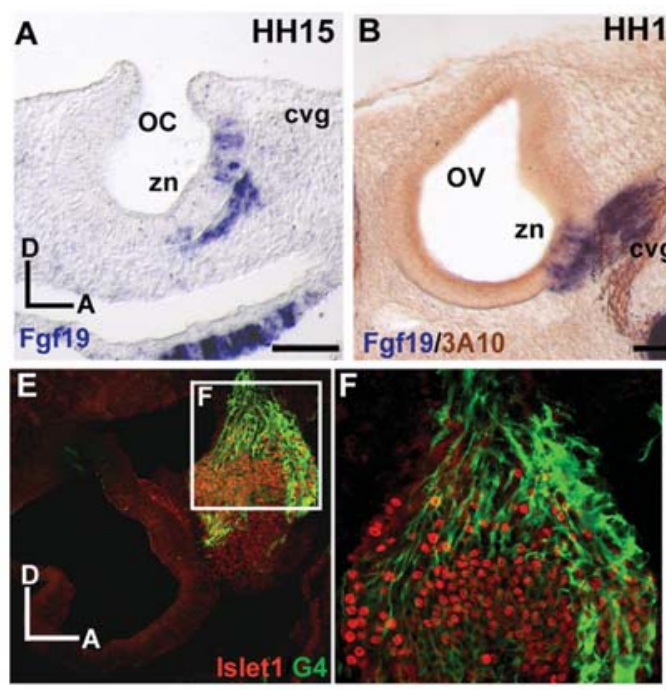

HH18
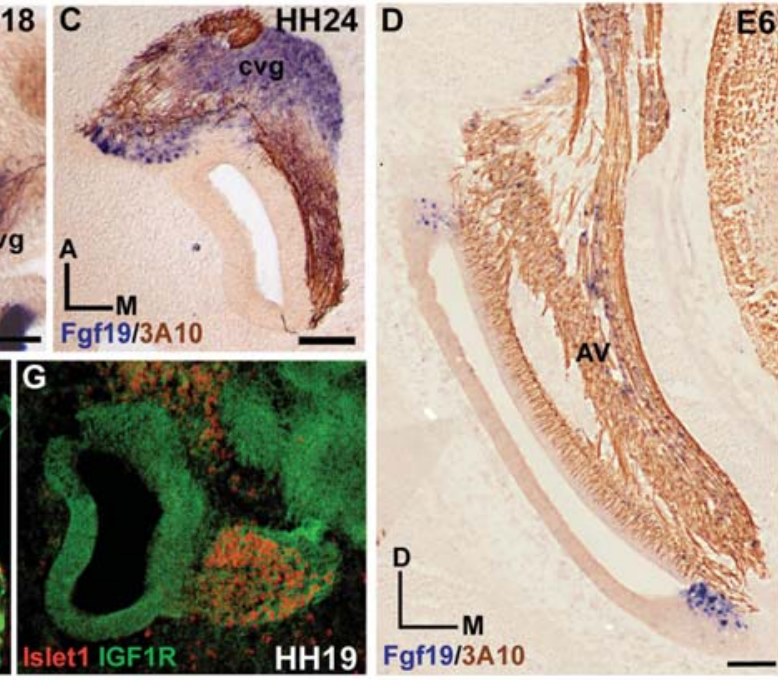

Fig. 1. Early inner ear neurogenesis. (A) Scheme representing the different steps and factors implicated in otic neuron development. (B) Early inner ear neurogenesis. The inner ear arises from the otic placode, which invaginates to form the otic cup (oc) and then the otic vesicle (ov), from which the adult inner ear ultimately derives $(\boldsymbol{C}, \boldsymbol{D})$. (A-D) Fgf19 transcripts were detected in delaminating neuroblasts by in situ hybridization, while 3A10 inmunoreactivity identifies otic axons (Modified from Sánchez-Calderonet al., 2007). Islet-1 and G4 expression in ganglion neuroblasts $(\boldsymbol{E}, \boldsymbol{F})$ and Islet-I and IGF1R expression in the otic vesicle (G). Abbreviations: CVG, cochlear-vestibular ganglion; $H C$, hair cell; INP, immature neural precursor; $M P e$, multipotent progenitor; $N B e$ epithelial neuroblast; $N B g$, ganglionar neuroblast; NP, neuronal precursor; OC, otic cup; OCE: otic cell epithelial; $O N$, otic neuron; $O V$, otic vesicle; SC, stem cell; ZN, neurogenic zone. Orientation: $A$, anterior; $D$, dorsal; $M$, medial. Scale bars: $A, 50 \mu m ; B-$ $D, 100 \mu \mathrm{m}$
2001; Brooker et al., 2006).

Another set of proneural genes, NeuroD and NeuroM, are expressed both in the otic cup epithelium and in the delaminating neuroblasts (Liu et al., 2000; Abu-Elmagd et al., 2001), suggesting that they act after the selection and specification of neural precursors. The null mouse for NeuroD exhibits deficient neuroblast delamination but it does not display alterations in the generation of neuronal precursors (Liu et al., 2000; Kim et al., 2001; reviewed in Chae et al., 2004). Therefore, the expression of NeuroD defines a second cell state in the neural lineage after neural fate specification, the epithelial neuroblast (NBe, Figure 1A).

Delamination of otic neuronal precursors has been studied extensively in the chicken embryo (D'Amico-Martel and Noden, 1983; Alvarez et al., 1989; Hemond and Morest, 1991). This delamination starts at the otic cup stage and their migration peaks when the otic cup closes to form the early otic vesicle. The delaminating cells are a population committed to a neural fate able to proliferate that constitutes a transit-amplifying cell population (Adam etal., 1998; Begbie et al., 2002). We can identify this third cellular state as the ganglionar neuroblast (NBg, Figure $1 \mathrm{~A})$.
The LIM-homeodomain gene family of transcription factors is crucial to specify the identity of neurons derived from the neural tube (Hobert and Westphal, 2000). Islet-1 is one member of this family that is expressed in a few cells within the epithelium, but it is intensely expressed in cells located at the sites of delamination and in those that have delaminated (Figure 1B, and Adam et al., 1998; Camarero et al., 2003; Li et al., 2004b). In addition to NeuroD and Islet-1, the mouse epithelial neuroblasts also express the alpha6 integrin subunit, which interestingly is not expressed in delaminated neuroblasts (Davies, 2007). The ganglionar neuroblasts make up a population characterised by the expression of NeuroD, Islet-1, neuron-specific $\beta$ III-tubulin, Tuj1 (Memberg and Hall, 1995; Camarero et al., 2003) and proliferation markers such as the proliferating cell nuclear antigen (PCNA) and phospho-histone 3 (Camarero et al., 2003). Although there are other fundamental elements involved, as discussed later, ganglionar neuroblasts depend on insulin-like growth factor I (IGF-I) for their survival, expansion and differentiation (Camarero et al., 2003). The mouse transcription factor Eya1 modulates the expression of the transcription factors $T b \times 1$ and of the proneural genes $\mathrm{Ngn} 1$ and $\mathrm{NeuroD}$, as well as that of the neurotrophins, 
brain derived neurotrophic growth factor (BDNF) and neurotrophin 3 (NT-3) (Friedman et al., 2005). Since Tbx 1 is expressed in the otocyst epithelium but is excluded from the prospective endolymphatic duct and proneural regions, it has been postulated that this gene could inhibit neural fate by suppressing Ngn1 and Delta1 expression (Raft et al., 2004; Xu et al., 2007).

After the last cycle of cell division, neuroblasts are post-mitotic and they become immature neurones, which then differentiate and extend projections towards their peripheral and central targets (Whitehead and Morest, 1985). These cells are immature neuronal precursors (INP, Figure $1 \mathrm{~A}$ ), a fourth cell state characterised by being post-mitotic but not yet differentiated. Accordingly, these precursors down-regulate the expression of most of the early neural genes and start to express another set of markers related to neurite extension and survival. These markers include fasciculin G4 (Fig. 1B; Camarero et al., 2003), the neurofilament associated antigen 3A10 (Adam et al., 1998; Camarero et al., 2003) and the TrkB and TrkC neurotrophin receptors (Brumwell et al., 2000; Kim et al., 2001, SanchezCalderon, unpublished observations). The final cellular state is that of a mature otic neuron (ON, Figure 1A), which generates action potentials and expresses synaptic receptors and neurotransmitters (Raphael and Altschuler, 2003).

Adult inner ear cells retain certain capacity to proliferate. Natural regeneration of the sensory hearing epithelia is displayed by teleosts, amphibians and birds. In contrast, there is no evidence of regeneration in the cochlear sensory epithelium or the cochlear ganglion neurons in mammals and only vestibular hair cells retain some capacity for regeneration. This lack of regeneration in the adult mammalian inner ear has made cell replacement therapy by transplanting extrinsic stem cells into the inner ear, or by activating intrinsic stem cells residing in the inner ear, an interesting proposition to counteract the degeneration and loss of sensory and neuronal cells (Hu and Ulfendahl, 2006). Several growth factors, including epidermal growth factor (EGF), IGF-I and basic fibroblast growth factor (bFGF) promote the proliferation of embryonic stem cells to produce inner ear precursors ( $\mathrm{Li}$ et al., 2003a and 2003b; Hu et al., 2005), in accordance with observations implicating these factors in the proliferation, differentiation and survival of developing inner ear cells (Leon et al., 1995; Zheng etal., 1997; Hossain and Morest, 2000; Ladher et al., 2000; Varela-Nieto et al., 2004). In particular, IGF-I has been shown to promote neural stem cell proliferation and survival in different contexts and to induce differentiation in combination with neurotrophins (Arsenijevic and Weiss, 1998; Arsenijevic et al., 2001) (Figure 1A).

It is clear that hair cells can be generated from embryonic and adult mammalian stem cells and that in some cases they can integrate into the developing chicken sensory field (Malgrange et al., 2002; Tateya et al., 2003; Li et al., 2003a, 2003b and 2004a). In contrast, there is only limited evidence for the presence of neuronal stem cells in the mammalian ear (Rask-Andersen et al., 2005). Therefore, an attractive alternative for the replacement of neurons lost from the cochlear ganglion is the transplantation of neural stem cells (Okano et al., 2005). These stem cells play a major role in the development of the embryonic central nervous system and their expansion depends on signals from the microenvironment in which they are found, including a number of growth factors such as IGF-I and bFGF (reviewed in Merkle and AlvarezBuylla, 2006; Doetsch, 2003). Adult mouse neural stem cells differentiate into a neuronal fate but only few survive in the inner ear. Nevertheless, it is promising that the survivors migrate to the spiral ganglion, the auditory nerve tract and the organ of Corti, where they differentiate and extend neurites into the auditory system of adult mammals (Hu et al., 2005; Hu and Ulfendahl, 2006).

\section{Otic neurogenesis is regulated by trophic factors}

\section{The Fibroblast Growth Factor family}

The FGF family is comprised of 25 members that have been implicated in different cell functions, including cell differentiation, proliferation, motility and survival (Wright and Mansour, 2003). Two of them, FGF24 and FGF25, have been identified in zebrafish (Fischer et al., 2003; Katoh and Katoh, 2005). FGF's act through the specific FGF receptors produced from four genes in mammals, which generate many different protein isoforms through alternative splicing (Wright and Mansour, 2003).

FGF2, FGF3, FGF8, FGF10 and FGF19 participate in otic neurogenesis (Table 1), and FGF16 is present in the otic vesicle epithelium in areas not associated with neurogenesis but rather with sensory organ specification (Chapman et al., 2006). Fgf2 (bFGF) is expressed in mouse and chicken otic placode and otic vesicle (Vendrell et al., 2000). This FGF augments the migration and differentiation of CVG neurons (Hossain et al., 1996; Zheng et al., 1997; Adamska et al., 2001) and it has been implicated in

TABLE 1

\section{DIFFUSIBLE FACTORS INVOLVED IN INNER EAR NEUROGENESIS}

\begin{tabular}{|c|c|c|c|c|c|c|}
\hline Factor & Migration & Proliferation & Survival & Apoptosis & Early Differentation & References \\
\hline Insulin & nd & + & nd & nd & - & Leon et al., 1995 and 1998. \\
\hline IGF-I & - & + & + & - & + & Leon et al., 1995; Frago et al., 2003 \\
\hline IGF-II & nd & + & nd & nd & nd & León et al., 1995 \\
\hline BDNF/TrkB & + & + & + & - & + & Farinas et al., 2001; Fritzsch et al., 2004 \\
\hline NT-3/TrkC & + & + & + & - & + & Fritzsch et al., 2004 \\
\hline NGF/p $75^{\text {NTR }}$ & nd & - & - & + & nd & Frago et al., 1998; Sanz et al., 1999a. \\
\hline FGF2 & + & + & + & - & + & Adamska et al., 2001; Nicholl et al., 2005 \\
\hline FGF3 & + & nd & + & nd & nd & Wright and Mansour, 2003 \\
\hline FGF8 & nd & - & nd & nd & nd & Adamska et al., 2001 \\
\hline FGF10 & - & - & - & - & + & Alsina et al., 2004 \\
\hline FGF19 & + & nd & nd & nd & + & Sanchez-Calderon et al., 2007 \\
\hline
\end{tabular}


A Intracellular pathways for IGF-I



B Endogenous IGF-I promotes CVG generation
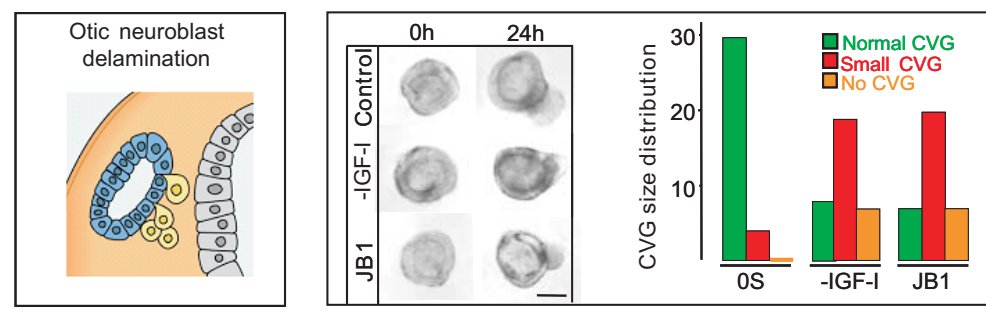

C

Exogenous IGF-I induces neuronal differentiation and survival
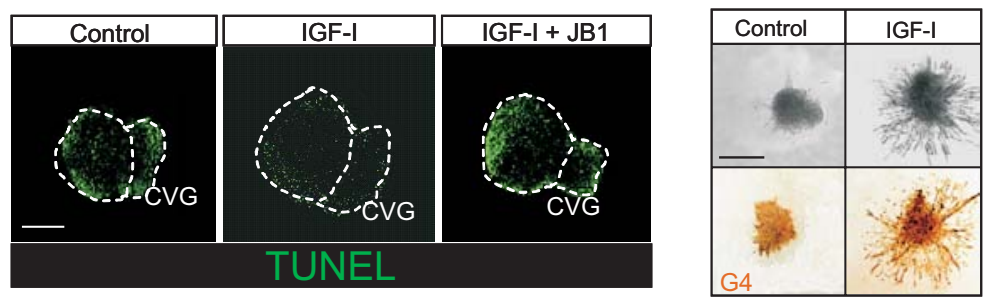

Fig. 2. IGF-I and neurogenesis: intracellular pathways and their implications in CVG generation, proliferation, neuronal differentiation and survival of otic neuroblasts. (A) Proposed signalling pathways involved in IGF-I-mediated neurogenesis and related process. Binding of IGF-I to the extracellular $\alpha$-subunits of its high affinity receptor (IGF1R) provokes its auto-phosphorylation on tyrosine residues in the $\beta$-subunits and the subsequent docking and phosphorylation of intracellular signalling proteins. The figure shows the two main pathways specifically activated by IGF-binding to IGF1R, the PI-3K/AKt pathway and the Raf/ MAPK pathway and their general role in neurogenesis (summarized from Feldman et al., 1997; Varela-Nieto et al., 2003; Russo et al., 2005; Ye and D'Ercole, 2006). Abbreviations: IRS, insulin-receptor substrate; PI3K, phosphoinositide-3 kinase; MAPK, mitogen-activated protein kinase. (B) Endogenous IGF-I is involved in chicken CVG generation. The function of IGF-I was explored in explants of otic vesicles by assessing the formation of the CVG in medium without additives (control) or in the presence of anti-IGF-I antibodies ( $\alpha-I G F-I)$ or the competitive receptor antagonist JB1. The scheme to the left represents the process of neuroblast delamination from the ventromedial part of the otic vesicle. The middle part illustrates representative photomicrographs of otic vesicles at the start of culture $(0 \mathrm{~h})$ and after 24 hours in culture with serum-free medium (Control), with $\alpha$-IGF-I antibodies and with JB1. The histogram to the right, presents the size distribution of ganglia generated from otic vesicle explants cultured under different conditions. Scale bar, $150 \mu \mathrm{m}$. Modified from Camarero et al., 2003. (C) Exogenous IGF-I promotes chicken neuroblast differentiation and survival. Photomicrographs show the effect of IGF-I on survival (TUNEL, left) and on differentiation in cultured CVG explants (G4, right). Scale bar: $C$, Control, $150 \mu \mathrm{m}$. Modified from Camarero et al., 2003.

etal., 1995). The CVG ganglion is diminished in mice carrying a null-mutation for Fgf3, on a background of morphogenetic defects (Mansour et al., 1993). Indeed, mouse embryos lacking both Fgf3 and Fgf10 fail to form otic vesicles and therefore, these two genes are clearly implicated in otic induction (Wright and Mansour, 2003; Alvarez et al., 2003). It was

the differentiation of sensory cells in the chicken embryo. However, the inner ear forms normally in mice lacking Fgf2 and no abnormalities are observed in adults (Carnicero et al., 2004; Sliwinska-Kowalska et al., 2005). Interestingly, FGF2 promotes BDNF activity by up-regulating its high affinity TrkB receptor in cultured mouse auditory neurons (Brumwell et al., 2000). Significantly, the sequential interaction between FGF2, BDNF, NT-3 and their receptors define critical periods of the development of auditory neurons (Hossain etal., 2002). Moreover, co-administration of FGF2 and glial cell line-derived neurotrophic factor (GDNF) supports the survival of adult mouse cochlear neurons in vitro, whilst FGF2 alone promoted neurite generation (Wei et al., 2006). Indeed, either FGF2 or FGF1 induced bipolar neurite formation in cultures of US/VOT-N33 (N33) cells, which are derived from mouse cochlear neuroblasts, a characteristic of mature cochlear neurons (Nicholl et al., 2005).

In mice and Xenopus, Fgf3 (Int2)mRNA is confined to the otic vesicle sensory epithelium and to the CVG (Wilkinson et al., 1989; Tannahill et al., 1992), but not in the chicken embryo (Mahmood recently shown that a human syndrome characterized by type I microtia, microdontia and profound congenital deafness due to the complete absence of inner ear structures is caused by any of three different homozygous mutation in FGF3(Tekin et al., 2007).

Fgf8 (A/GF) is expressed in the chicken otic vesicle and later in the CVG (Colvin et al., 1999) and it is implicated in zebrafish, chicken and mouse otic induction (Leger and Brand, 2002; Ladher et al., 2005; Hans et al., 2007). Both loss of function of Fgf8 in zebrafish and the knock down of Fgf3with antisense morpholinos cause profound alterations in the induction and formation of the otic vesicle (Phillips et al., 2001; Hans et al., 2007). However, little is known about the alterations of sensory neurons or sensory receptors under these circumstances. The formation of the otic placode in the chicken and mouse requires at least two signals, one from the mesoderm and one from the ectoderm. In the chicken, the mesodermal signal is FGF19 while in the mouse it is FGF10. Moreover, a signal from the endoderm is necessary for FgfB to induce mouse and chicken otic development (Ladher et al., 2005). Previous studies in the chicken showed that the ectopic 
application of FGF2 and FGF8 enhances the transcription of several otic patterning genes and enlarges the CVG (Adamska et al., 2001), supporting a role for FGF8 in the generation of the CVG (Hossain et al., 1996). Moreover, delaminating neuroblasts are observed at the boundary between the domains of chicken Fgf8 and Otx2 expression (Hidalgo-Sanchez et al., 2000; SanchezCalderon et al., 2004).

Fgf10 mRNA is expressed in the chicken and mouse otic placode and otic vesicle, within the proneural-sensory epithelium. Indeed, Fgf10 in the mouse is also expressed in CVG neurons (Pirvola et al., 2000; Alsina et al., 2004; Lilleväli et al., 2006) and overexpression of chicken Fgf10 increases the number of cells expressing NeuroD and NeuroM, but not Delta1 (Alsina et al., 2004). The number of otic neurons is reduced in mouse null mutant for Fgf10and defects are detected in the sensory epithelium (Pauley et al., 2003). Based on binding studies, FGFR-2IIIb is thought to be the target of FGF10, although this factor also binds to FGFR-1 (Powers et al., 2000). Fgfr-2 is expressed dorsally in the prospective non-sensory epithelium of the otocyst, whereas Fgf10and Fgf3are co-expressed with neurotrophins in the ventral domain, suggesting that FGFs and FGFRs may act in a paracrine manner (Pirvola et al., 2000). FGFR-2IIlb null mutants fail to form the CVG at early stages and although the detailed mechanism remains unknown neural precursors are probably affected. Disruption of FgfR1, the other potential receptor for FGF10, causes defects in the organ of Corti associated with the reduced proliferation of the precursor pool that generates the auditory sensory epithelium (Pirvola et al., 2002). Moreover, FGF10 signalling was proposed to be regulated by GATA3, a zinc finger transcription factor (Ohuchi et al., 2005; Lillevali et al., 2006).

Finally, mouse FGF15 is the homologue of chicken and human FGF19 (Wright etal., 2004). Mesodermal chicken Fgf19has been implicated in otic induction (Ladher et al., 2000; Wright et al., 2004) and it is expressed both in the ganglionar neuroblasts delaminating from the otic epithelium and in the CVG (Figure 1B). FGF19 transcripts remain in the CVG until E8, suggesting a relationship between this factor and neural differentiation (Figure 1B) (Sanchez-Calderon et al., 2007). Fgf19 and Fgf8 mRNA expression determine two subdomains within the Fgf10-positive proneural-sensory territory (Sanchez-Calderon et al., 2007). Human FGF19 appears to bind only to FGFR4 (Xie et al., 1999), which is expressed in the chicken and mouse neuroectoderm and in the chicken mesoderm (Wright et al., 2004). In the mouse, Fgf15 is not expressed in the CVG and accordingly, Fgf15 null mutants do not display clear otic abnormalities (Wright et al., 2004). Thus, FGF signalling clearly plays an important role in every aspect of the development and innervation of the ear. Hence, it will be interesting to explore of FGF-cooperation or looping and the interactions of these factors with other growth factors during otic neurogenesis.

\section{Nerve growth factor and neurotrophins}

The neurotrophin (NT) family is made up of the small, basic, secreted proteins: nerve growth factor (NGF), brain-derived neurotrophic factor (BDNF), neurotrophin-3 (NT-3) and neurotrophin$4 / 5$ (NT-4/5). These proteins are essential for neuronal survival and differentiation (reviewed by Bibel and Barde, 2000; Huang and Reichardt, 2001; Pirvola and Ylikoski, 2003) and they mediate their effects through two types of receptors: the low affinity p75 neurotrophin receptor ( $p 75^{\mathrm{NTR}}$ ), a modulator of cell survival and cell death; and the Trk tyrosine kinase receptors that interact specifically with NGF (TrkA), BDNF (TrkB) and NT3 (TrkC) (Casaccia-Bonnefil et al., 1999; Barrett, 2000; Lee et al., 2001; Chao and Bothwell, 2002). Both NT-3 and BDNF, but not NGF or NT-4/5, are expressed in the inner ear sensory epithelia and in delaminating neuroblasts suggesting an early source of neurotrophic support for newborn CVG cells (Farinas et al., 2001; Friedman et al., 2005). The high affinity receptors TrkB (BDNF) and TrkC (NT3) receptors are expressed in otic sensory neurons and, while cochlear neurons depend on NT-3, vestibular neurons depend on BDNF for survival and differentiation in chicken, mouse and humans (Table 1) (reviewed in Fritzsch et al., 2004). Indeed, the majority of cochlear neurons are lost during inner ear development between E13.5 and E15.5 in NT3 ${ }^{-1-}$ mutant mice. The double $B D N F$ and TrkB mutant mainly lose vestibular neurons and in BDNF/NT-3 or TrkB/TrkC double homozygous mutants all cochlear and vestibular neurons are lost (Bianchi et al., 1996; Fritzsch et al., 1998 and 2004; and reviewed in Pirvola and Ylikoski, 2003). Specific binding of NGF to the TrkA receptor is involved in growth, survival and differentiation of neurons in the central nervous system (Williams et al., 2006). NGF is not expressed in the inner ear, but Trk $A$ is localised in the earlydeveloping CVG (Pirvola et al., 1994; Schecterson and Bothwell, 1994; Farinas et al., 2001) and in the adult mouse and rat organ of Corti. Hence, NGF may exert a specific effect on the peripheral auditory system (Dai et al., 2004). The development and survival of spiral ganglion neurons depends on neurotrophic factors such as NT-3 and GDNF (reviewed in Roehm and Hansen, 2005). In stem cells obtained from adult human and guinea pig spiral ganglions, neural differentiation and neurite outgrowth is induced by BDNF, GDNF and NT-3 (Rask-Andersen et al., 2005). Neurons differentiated from human progenitors co-express receptors for neurotrophic factors such as TrkB and TrkC (Rask-Andersen et al., 2005), consistent with the co-expression of these receptors in auditory neurons (Pirvola et al., 1992; Farinas et al., 2001). On this basis, neurotrophic factors have been proposed as candidates for pharmacological treatment to prevent secondary auditory nerve degeneration and to promote neurite re-growth following hearing loss (reviewed in Atar and Avraham, 2005; Holley, 2005).

All neurotrophins bind to $\mathrm{p} 75^{\mathrm{NTR}}$, which also interacts with Trk receptors to modulate ligand binding specificity, affinity, and function in certain cell types (Benedetti et al., 1993; Bibel et al., 1999). Mature neurotrophins preferentially bind to Trk receptors whereas the immature "proforms" of these proteins have higher affinity for $p 75^{\mathrm{NTR}}$, which fulfils a critical role in controlling the balance between cell survival/death. Sortilin acts as a co-receptor for p75 NTR essential for pro-neurotrophin-induced cell death (Nykjaer et al., 2004). The p75 NTR receptor is encoded by two proteins, the full-length (FL-p75 NTR) and short (S-p75 NTR) isoforms of p75 (Von Schack et al., 2001). Indeed, NGF induces apoptotic cell death in organotypic cultures of otic vesicles and in the CVG through binding to $7^{\mathrm{NTR}}$ in the chicken (Table 1) (Frago et al., 1998; Sanz et al., 1999a). Moreover, NGF-induced cell death only occurs in specific areas of the otic vesicle and CVG. The presence of $\mathrm{p} 75^{\mathrm{NTR}}$ has been reported at different stages of inner ear development in several animal species, and $\mathrm{p} 75^{\mathrm{NTR}}$ expression has been associated with the early specification of vestibular 
sensory patches in the chicken embryo (von Bartheld et al., 1991; Schecterson and Bothwell, 1994; Wu and Oh, 1996; Frago et al., 2003 and 2006). The precise signalling pathway(s) used by p $75^{\text {NTR }}$ to activate cell death remain unclear. They may involve the generation of ceramide (Frago et al., 1998 and 2006; Hirata et al., 2001) and the activation of Jun-N-terminal kinase (Sanz et al., 1999a; Harrington et al., 2002), the caspase cascade (Gu et al., 1999; Troy et al., 2002; Frago et al., 2003) and cyclin-dependent kinases (Frade, 2000). The pro-apoptotic activity of NGF/p75 NTR during early chicken neurogenesis is strictly controlled by survival factors such as IGF-I (Frago et al., 2003). In mice carrying a null mutation for the FL-p75 NTR but that still expressing S-p75 ${ }^{\text {NTR }}$, there is progressive hearing loss four months after birth, which is associated with the degeneration of cochlear neurons and hair cell loss at the basal turn of the cochlea. It was proposed that p75 NTR may play a significant role in the maintenance of cochlear function and that mice carrying a mutation in the $p 75$ gene could represent a new animal model of early onset progressive hearing loss (Sato et al., 2006). These data contrast with that suggesting that the activation of $\mathrm{p} 75^{\mathrm{NTR}}$ is associated with cell death in the adult cochlea. In a normal cochlea, the hair and supporting cells of the organ of Corti produce mature BDNF that activates TrkB receptors on cochlear neurons, triggering their survival. After aminoglycoside administration, sensory cells of the organ of Corti progressively degenerate, reducing the availability of mature BDNF and producing a decrease in TrkB expression. In parallel, p75 ${ }^{\text {NTR }}$ expression and c-Jun phosphorylation augments in cochlear neurons, suggesting an activation of apoptotic pathways when pro-survival neurotrophic support is diminished (Tan and Shepherd, 2006).

New insights into the activity of profactors and the transcriptional regulation of the genes encoding neurotrophins and their receptors have re-kindled interest in these elements. Thus, by controlling cell death and survival decisions the NGF family of neurotrophins contributes to inner ear development and the maintenance of its activity. Therefore, these elements may be of interest for hearing protection and regeneration.

\section{The insulin-like growth factor system in inner earneurogenesis}

The insulin gene family is made up of insulin, the insulin-like growth factors (IGF) I, II, relaxin and several insulin like peptides in different species (reviewed in Russo et al., 2005). Indeed, the gene encoding IGF-I is highly conserved in mammals, birds and amphibians (reviewed in Russo et al., 2005). Insulin-like peptides bind to specific receptors in the plasma membrane of target cells which can be grouped into two categories, the tyrosine kinase receptors (insulin receptor and IGF1R) and the mannose-6-phosphate IGF2R. In addition, the activity of IGF is modulated by a family of plasmatransporters referred to as the IGF binding proteins (IGFBP).

The actions of IGF-I are mediated by IGF1R, whose gene has also been highly conserved during evolution (Fig. 2A). IGF1R is a heterotetrameric transmembrane protein containing two $\alpha$ (extracellular ligand-binding) and two $\beta$ (intracellular) subunits with protein tyrosine kinase activity (LeRoith et al., 1995). Proinsulin and insulin are also able to bind to this receptor with high affinity and both are abundant in serum, typically masking the activity of IGFI. The IGF-I protein displays an amino acid identity above $91 \%$ in the tyrosine kinase encoding domain in animals as divergent as Xenopus, fish, chicken, rat and human (Russo et al., 2005). In the zebrafish embryo, Igf1r is expressed abundantly, particularly in the tail, eye, ear primordia and brain (Ayaso etal., 2002). The inhibition of IGF1R signalling during zebrafish embryogenesis causes significant defects in the inner ear that are accompanied by reduced embryonic growth, arrested development, increased lethality and induced neuronal apoptosis (Schlueter et al., 2007).

During embryogenesis, Igf- 1 and Igf1r mRNA are expressed in brain regions where there is active nerve sprouting in spinal and sensory ganglia and in cranial and spinal nerves (reviewed in Varela-Nieto et al., 2003). However, the transcription of the IGF-I and IGF1R genes declines significantly postnatally and reaches very low levels in the adult, a decrease that is correlated with the degree of cell maturation (reviewed in Varela-Nieto et al., 2003). Nonetheless, both proteins are still present in neurons and Schwann cells of the autonomic and peripheral nervous systems, as well as in structures of the central nervous system that undergo cell renewal in adulthood, such as the olfactory bulb, choroid plexus and the dentate gyrus of the hippocampus (reviewed in VarelaNieto et al., 2003). Both IGF-I and IGF-II appear to be able to increase the number of neural brain cells and prevent neuronal apoptosis (reviewed in Varela-Nieto et al., 2003; Russo et al., 2005; Ye and D'Ercole, 2006). IGF induces growth and DNA synthesis in a variety of neuronal cell types in vitro, including the neurons of the CVG (Leon et al., 1995). IGF-I shortens the length of the cell cycle in neuronal progenitors during embryonic life and influences the growth of all neural cell types (reviewed in VarelaNieto et al., 2003; Ye and D'Ercole, 2006). IGF-I may also act as a competence factor, a factor required for other growth factors to act. For example, in the absence of IGF-I neither EGF nor FGF-2 were able to stimulate proliferation of cultured neural stem cells from E14 mouse embryos (Arsenijevic et al., 2001). However, the role of IGF-I in cell lineage specification remains controversial, possibly due to species specific activity.

IGF-I is also required for the early differentiation and survival of neuroblasts in the chicken otic vesicle (Table 1; Fig. 2B) (Camarero et al., 2003). IGF-I and IGF1R are expressed in the developing chicken otic epithelium and CVG (Camarero et al., 2003) and in the postnatal cochlear and vestibular ganglia (Camarero et al., 2001 and 2002; reviewed in Varela-Nieto et al., 2003 and 2004). In organotypic cultures of chicken otic vesicles, the addition of exogenous IGF-I causes an increase in cell number in the otic vesicle and its associated CVG, mimicking the normal pattern of in vivo morphogenesis (Leon et al., 1995). Addition of exogenous IGF-I to the isolated chicken CVG increases cell proliferation, causes neurite outgrowth and elevates the expression of the neuronal differentiation marker G4 (Camarero et al., 2003) (Fig. 2C). Blockage of endogenous IGF-I activity inhibits CVG formation in growth factor-free medium and increases cell death, revealing that endogenous IGF-I activity is essential for ganglion generation and survival (Camarero et al., 2003). These studies suggest that proliferation, differentiation and survival of neural progenitors and neurons of the inner ear are dependent on IGF-I.

Even though much progress has been made in recent years, the intracellular signaling pathways that mediate organ-specific IGF-I activity remain to be clarified. The response of target cells to IGFI is mediated by its high affinity receptor, IGF1R, a classic transmembrane tyrosine kinase receptor. IGF1R is expressed in multiple neural tissues in the embryo and its activation plays an important role in both proliferation and neuronal differentiation during embryonic development and also in regeneration (reviewed 
in Varela-Nieto et al., 2003). Binding of IGF-I to IGF1R activates distinct signalling cascades, which in turn mediate the trophic effects of IGF. Tyrosine kinase activity results in the autophosphorylation of IGF1R and triggers the activation of two main intracellular signalling pathways: the phosphatidylinositol-3 kinase/Akt (PI-3K/Akt) survival pathway; and the Raf/mitogenactivated protein kinase (Raf/MAPK) that activates the proliferation of neuronal cells during development (reviewed in Varela-Nieto et al., 2003; Russo et al., 2005). Recently, IGF-I treatment has been shown to promote a neuronal phenotype in mouse olfactory bulb stem cells by regulating the PI-3K/Akt pathway (Otaegi et al., 2006; Kalluri et al., 2007) and significantly, IGF-I can activate these pathways during early development of the otic vesicle (Sanz et al., 1999b; Frago et al., 2003). The activation of the Raf/MAPK cascade is involved in the proliferation of the epithelial inner ear cells, whereas the activation of PI3-kinase/Akt pathway controls otic cell survival (Sanz et al., 1999b; Frago et al., 2003; Leon et al., 2004). In addition to canonic intracellular pathways, ceramide kinase has also been proposed as a key target in IGF-I protective pathways (Sugiura et al., 2002; Frago et al., 2003 and 2006).

Insight into the role of IGFs in inner ear cochlear ganglion neurogenesis has come from the study of genetically modified mice. While there is an increase in cell size and less apoptosis in a transgenic mouse over-expressing IGF-I (reviewed in VarelaNieto etal., 2003 and 2004), conversely there is growth retardation, reduced brain size, loss of selective neuronal populations, hypomyelinization and reduced peripheral conduction velocities in mice lacking IGF-I ( $/ g f 1^{-1}$ ) (Figure 3) (reviewed in Varela-Nieto et al., 2003 and 2004). In addition, postnatal cochlear development is severely impaired in mice $/ g f^{\%}$, which develop smaller cochlea and cochlear ganglia, an immature tectorial membrane and they display a significant decrease in the number and size of auditory neurons (Camarero et al., 2001 and 2002). The marked reduction in neural cell number seems to be due to multiple processes, including increased cell death (Camarero et al., 2001). These results demonstrated that IGF-I contributes to the maturation and maintenance of cochlear neurons. In addition, the myelin sheath that envelops the bipolar neurons of the postnatal vertebrate cochlear nerve is severely affected (Camarero et al., 2002). In summary, lack of IGF-I in mice affects the postnatal survival, differentiation and maturation of cochlear ganglion cells and causes abnormal innervation of the sensory cells in the organ of Corti. Interestingly, mutations in the gene encoding human IGF-I cause syndromic neurosensorial hearing loss (Woods et al., 1996 and 1997; Walenkamp et al., 2005; Walenkamp and Wit, 2006). Furthermore, IGF-I deficit in the mouse causes all-frequency bilateral sensorineural hearing loss and a delayed response to acoustic stimuli (Cediel et al., 2006) (Figure 3N). In the diseased or injured nervous system, IGF-I infusion enhances nerve regeneration and in vitro, stimulates regeneration of adult sensory neurons (reviewed in Varela-Nieto et al., 2003). Hence, IGF-I may be used as a treatment cofactor to combat hearing loss.

\section{Transcription factors and gene networks}

During the development of the inner ear there are several families of transcription factors that are implicated in defining boundaries and polarity and in the regulation of intracellular signalling (Table 2). It follows a brief overview of the transcription factors that are expressed in the inner ear during the stages of early neurogenesis.

\section{Zinc finger transcription factors}

Two of the six members of the GATA family of zinc finger transcription factors are expressed in the inner ear, GATA3 and GATA2 (Lillevali et al., 2004). Their expression overlaps in the mouse otic vesicle at E9.5-10.5 but during subsequent development, it diverges considerably. GATA3 is confined to the sensory

TABLE 2

\section{TRANSCRIPTION FACTORS IMPLICATED IN OTIC NEUROGENESIS}

\begin{tabular}{|c|c|c|c|c|}
\hline Gene Name & Description & Family & Proces & References \\
\hline Gata3 & Gata3 zinc finger & Zinc fingers & $\begin{array}{l}\text { Expressed only in auditory neurons. } \\
\text { Selective loss of cochlear ganglion } \\
\text { neurons in the null mouse. }\end{array}$ & $\begin{array}{l}\text { Lillevali et al., 2004; Lawoko-Kerali et al., } \\
2002 \text { and 2004; Karis et al., } 2004\end{array}$ \\
\hline Gata2 & Gata2 zinc finger & Zinc fingers & nd & Lillevali et al., 2004; Holley et al., 2007 \\
\hline Gfi1 & Growth Factor Independence 1 & Zinc fingers & Hair cells differentiation and survival & Wallis et al., 2003 \\
\hline Brn3a & $\begin{array}{l}\text { POU domain, class } 4 \text {, } \\
\text { transcription factor } 1\end{array}$ & POU domain & $\begin{array}{l}\text { Growth and migration of sensory neurons; } \\
\text { innervation and axon guidance }\end{array}$ & Huang et al., 2001a \\
\hline Brn3c & $\begin{array}{l}\text { POU domain, class } 4 \text {, } \\
\text { transcription factor } 3\end{array}$ & POU domain & Hair cell differentiation & Xiang et al., 1997; Zheng et al., 2000 \\
\hline Ngn1 & Neurogenin 1 & $\begin{array}{l}\text { Basic helix-loop-helix } \\
\text { (bHLH) }\end{array}$ & Differentiation of all inner ear sensory neurons & Ma et al., 1998 \\
\hline NeuroD & Neurogenic differentiation 1 & bHLH & $\begin{array}{l}\text { Survival of inner ear sensory neurons. } \\
\text { The NeuroD null mouse presents a general loss of } \\
\text { otic neurons, being more affected the cochlear ones. }\end{array}$ & Liu et al., 2000†; Kim et al., 2001 \\
\hline Hes1 & Hairy and enhancer of split 1 & bHLH & Ear histogenesis; effectors for the Notch pathway & Zine et al., 2001; Kageyama et al., 2005 \\
\hline Hes3 & Hairy and enhancer of split 3 & bHLH & Effectors for the Notch pathway & Kageyama et al., 2005 \\
\hline Hes5 & Hairy and enhancer of split 5 & bHLH & Ear histogenesis; effectors for the Notch pathway & Zine et al., 2001; Kageyama et al., 2005 \\
\hline Atoh1 & Atonal homolog 1 & bHLH & Hair cell differentiation & Bermingham et al., 1999 \\
\hline Isl1 & Islet 1 & $\begin{array}{l}\text { LIM homeodomain } \\
\text { (LIM -HD) }\end{array}$ & $\begin{array}{l}\text { Development of both sensory and neuronal lineages } \\
\text { of inner ear }\end{array}$ & Radde-Gallwitz et al., 2004; Li et al., 2004b \\
\hline
\end{tabular}


domains, epithelial cells, auditory sensory neurons (spiral ganglion neurons) and periotic mesenchyme (Lawoko-Kerali et al., 2002) and by E18.5 it becomes restricted to the cochlea. Without GATA3 a small otic vesicle forms while the cochlear duct, the semicircular canals and auditory ganglion fail to develop (Karis et al., 2001). Its expression is particularly high in spiral ganglion neurons during migration and differentiation (Lawoko-Kerali et al., 2004) and it is specifically down-regulated in hair cells when they start to differentiate within the sensory fields (Rivolta and Holley, 1998). There is evidence that GATA3 regulates the expression of the transcription factor NeuroD (Lawoko-Kerali, 2004), as well as that of Fgf10 in otic epithelium (Lillevali et al., 2006).

The role of GATA2 in the inner ear is not yet clear and no abnormalities in early otic development have been observed in Gata2deficient embryos (Lillevali et al., 2004). However, a recent microarray study of GATA2 functionally related genes based on the similarity of expression patterns in inner ear cell lines have identified interesting co-regulated genes such as the signal transducer and activator of transcription, Stat3 (Holley et al., 2007).

Another zinc finger transcription factor that is expressed in the inner ear is the growth factor independence 1 (Gfin), which is essential for hair cell differentiation and survival (Wallis et al., 2003; Hertzano et al., 2004).

\section{POU domain transcription factors}

There are two members expressed in the inner ear: Brn3aand $B r n 3 c$. Brn3a is required for proper growth and migration in the inner ear and gustatory sensory neurons and it is critically involved in target innervation and axon guidance by spiral and vestibular ganglion neurons. Brn3a controls survival and differentiation of sensory neurons by regulating different downstream genes. Loss of Brn3a results in severe retardation in the development of axon projections to the cochlea and the posterior vertical canal as early as E13.5. In addition, efferent axons that use the afferent fibers as a scaffold during pathfinding also show severe misrouting (Huang et al., 2001).

$B r n 3 c$ is specifically expressed by hair cells within the adult mice inner ear; moreover, Brn3c null mutant mice contain immature hair cells but have a normal development of cochlear innervation (Xiang et al., 1997 and 2003). Ectopic overexpression of $B r n 3 c$ does not lead to the production of hair cells, indicating that it is only required for the later aspects of hair cells differentiation (Zheng and Gao, 2000).

\section{bHLH transcription factors}

During development of the otocyst the auditory and vestibular neuroblasts are amongst the first cell types to be specified (Hemond and Morest, 1991; Hossain and Morest, 2000; Fekete and $\mathrm{Wu}, 2002)$. They migrate from the prospective neural-sensorial domain epithelium at E9.5-10.5, simultaneously down-regulating epithelial cytokeratin. Their differentiation depends on the two basic helix-loop-helix (bHLH) transcription factors, neurogenin 1 (Ngn1) and NeuroD. In null mutants for Ngn 1, both auditory and vestibular neurons are absent, showing that this gene is essential for the differentiation of all inner ear sensory neurons (Ma et al., 1998). Indeed, it was suggested that NeuroD and $\beta$ III-tubulin are part of the same regulatory cascade downstream of Ngn1 (Ma et al., 1998). In null mutants for NeuroD, both auditory and vestibular neuroblast migration is compromised, although there is greater depletion of auditory ganglion neurons (Liu et al., 2000; Kim et al., 2001). Other bHLH genes are necessary to realize the full proliferative capacity of progenitor neurons: Hes1, Hes3, Hes5 (Kageyama et al., 2005). Hes5 and Hes1 are relevant for ear histogenesis (Zine et al., 2001) since they appear to interact with Notch signalling in supporting cells and with Atoh 1 in hair cells (Zheng et al., 2000; Lanford et al., 2000). Atoh1 is a bHLH transcription factor and it is 'necessary and sufficient' for hair cell differentiation (Bermingham et al., 1999).

\section{LIM-HD transcription factors}

Islet-1 $(/ s /-\eta)$ is a transcription factor belonging to the LIM homeodomain (LIM-HD) family. In the nervous system, the cooperation between the bHLH and LIM-HD transcription factors is responsible for generating cell diversity. As described earlier, Islet-1 is expressed in the otic neurogenic zone (Li et al., 2004b). Its expression is later maintained in otic neurons but is lost in the sensory lineages (Radde-Gallwitz et al., 2004).

\section{Microarrays and gene networks}

One very unique aspect of the ear is the complex combination of forms and functions that enable the reception and the transduction of specific physical sensations. As an additional level of complexity, the precise geometry of the inner ear permits the interpretation of only certain mechanical stimuli. Very little is known about the molecular interactions and the genetic hierarchies that guide the morphogenesis of such a specialized epithelium. In the effort to unravel the regulatory gene networks that characterize the development and the maturation of the inner ear organs, new experimental techniques such as microarray analyses have been employed.

Microarrays provide a practical means to measure the expression of thousand of genes simultaneously (Schena et al., 1995; Lockhart et al., 1996). They have been successfully applied to the study of gene expression patterns in inner ear cell differentiation in vitro (Rivolta et al., 2002) and more recently, in the studies of gene expression changes in the cochlea following exposure to noise and ageing (Kirkegaard et al., 2006; Gong et al., 2006). Very early attempts have also been made to analyse changes in gene expression during embryonic stem cell differentiation along the inner ear cells pathways (De Silva et al., 2006). However, this technology is associated with many significant sources of experimental uncertainty that makes the data analysis very challenging. In studies of complex biological systems like the inner ear, the gene expression signal of fundamental processes may often be in the same order of magnitude as the background noise and therefore, very difficult to detect. For this reason the uncertainty generated by the experimental and biological noise must be carefully analyzed and quantified in order to obtain meaningful information from the data. An estimate of uncertainty is not fully achieved using repeat experiments because outliers are often due to flaws in the microarray technique, or to problems in the hybridization of the biological material. The most commonly used microarrays are high-density oligonucleotide arrays, such as Affymetrix GeneChip®. They are characterized by multiple probes associated with each target paired as perfect match (PM) probes and mismatch (MM) probes. The probe-set is used to measure levels of target gene expression and this measurement is then 

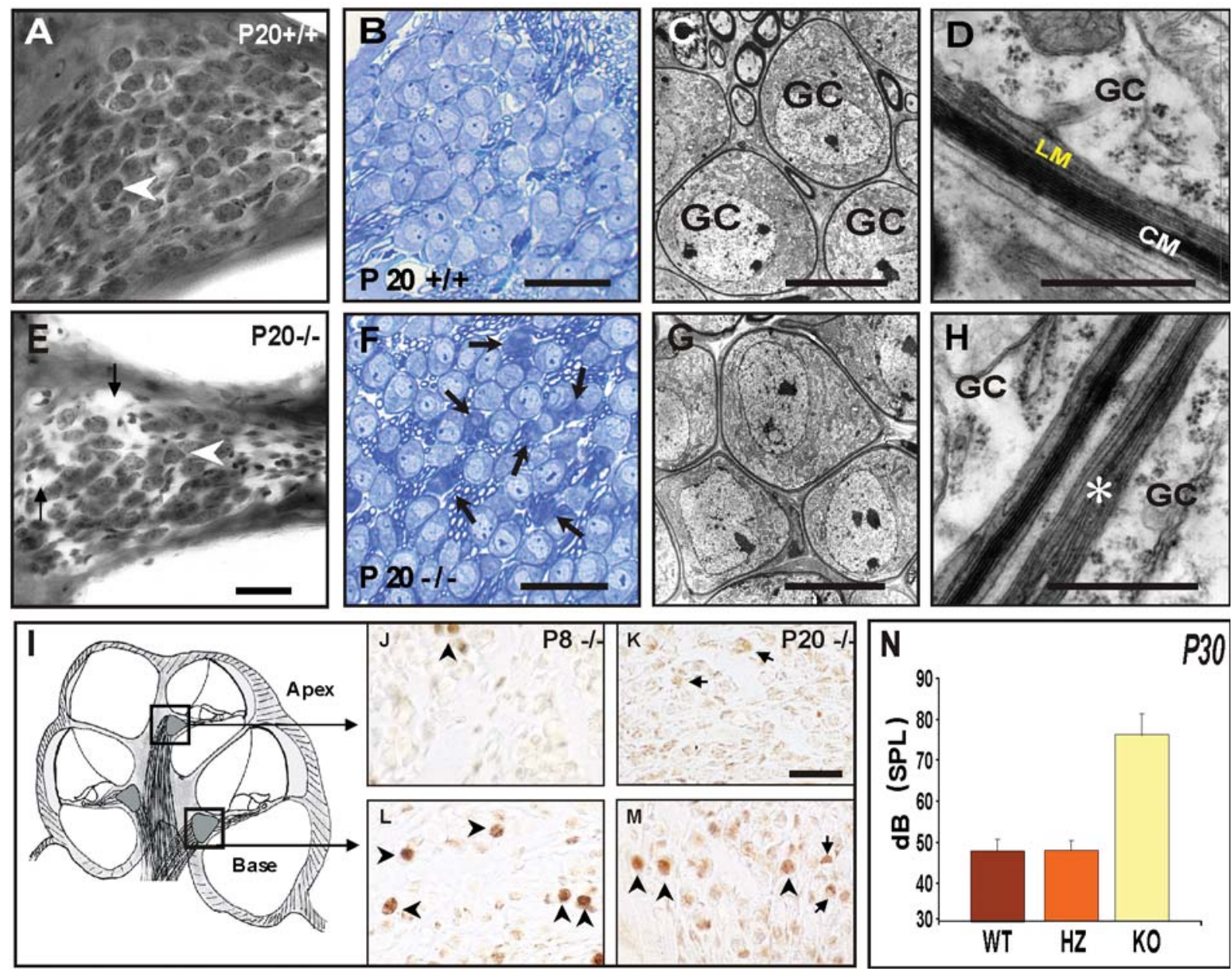

Fig. 3. Cochlear ganglion abnormalities in the Igf $\boldsymbol{1}^{--}$mutant mouse. Normal lgf-1 ${ }^{+/+}$ganglia are shown in $(A-D)$ and mutant Igf- $1^{-/}$ganglia in $(E-$ H). (A) Aspect of a normal P20 cochlear ganglion. (B) Toluidine blue staining of the cochlear ganglion. (C) Electron micrographs of the normal aspect of ganglion cells (GC), with their intact myelin sheaths. (D) Detail of the myelin sheath of a normal neuron with the external compact myelin (CM) and the internal loose myelin (LM). (E) Aspect of a mutant P20 cochlear ganglion. (F) Toluidine blue staining of the cochlear ganglion in mutant mice. Note the pyknotic cells (arrows) that are probably degenerating neurons. (G) Electron micrograph of an apparently normal group of ganglion cells. (H) Detail of the myelin sheath of a mutant mouse neuron. Note the thinner compact myelin and the non-compacted sheath (asterisk). (I) Schematic drawing of the cochlea in which the squares indicate the apical and basal turn cochlear ganglia. (J-M) TUNEL labelling from normal(Igf-1+/+) and mutant (Igf-1\%) mice at postnatal days 8 and 20. The number of apoptotic neurons increases in the cochlear ganglion of Igf- $1^{-\%}$. (N) Average ABR thresholds for click stimulus of Igf-1+/+ $(n=21)$, Igf-1 ${ }^{+/}(n=29)$ and Igf-1-/- $(n=11)$ mice. Data are presented as mean \pm SEM. The difference was statistically significant $\left.{ }^{*}{ }^{*} P<0.01\right)$ between the null group and the wild-type and heterozygous groups. Scale bars: $(A, E) 30 \mu \mathrm{m} ;(B, F) 30 \mu \mathrm{m} ;(C, G) 10 \mu \mathrm{m} ;(D, H)$ $0.5 \mu \mathrm{m}$. Modified from: Camarero et al., 2001 and 2002; Cediel et al., 2006.

utilized to detect genes differentially expressed between different conditions, to visualize clustering or to define gene networks. To estimate gene expression levels a summary of these probe-level values is required. The level of uncertainty associated to low gene expression signals is very high and a summary that is less sensitive to the noise is needed. The most popular methods to analyse probe-levels at present only provide a single point estimate of the gene expression levels but most of them are unable to provide credibility intervals for each measurement. (Affymetrix, Microarray Suite User Guide version 5.0., 2001, Affymetrix Inc.) (Irizarry et al., 2003). Probabilistic models have been introduced more recently that describe the probe data set in terms of probabilistic functions. The Bayesian Gene Expression (BGX, http://www.bgx.org.uk/; Hein et al., 2005) has developed a Hier- archical Bayesian model for probe-level analysis but it is computationally very expensive and therefore not feasible to run on very large datasets. An affordable alternative are the models developed by PUMA group (Propagating Uncertainty in Microarray Analysis, http://www.bioinf.man.ac.uk/resources/puma/) and the gMOS models (gamma model of oligonucleotide signal) show improvements both in accuracy and computational efficiency over the BGX model. They estimate gene expression levels with credibility intervals that quantify the measurement variance associated with the estimates of target concentration within a sample. This within sample variance is a significant source of uncertainty in oligonucleotide arrays, especially for weakly expressed genes. These models also run efficiently and perform accurately on different types of data including inner ear data (Milo et al., 2003; 
Liu et al., 2005; Holley et al., 2007). A still ongoing microarray study on the $/ g f^{-1-}$ null mutant carried out by Sanchez-Calderon et al., has shown that using a sensitive probe-level analysis, such as gMOS and related models, very low expression of signals can be detected in highly variable biological samples. Such types of gene expression analysis were not successful when performed with models that do not quantify variance at the probe-level. The high number of false positives made the detection of true positives almost impossible. However, the results obtained from gene expression analysis are now being validated in vivo.

Although microarray technology is becoming more affordable, there is still an increasing demand for robust bioinformatics tools to analyse large scale gene expression data. The high cost of arrays and the limitations in performing biological experiments, due to the lack of biological material and/or the complexity of the system makes it even more important to have robust predictions in silico before undertaking in vitro or in vivo experiments. Developing mathematical models that integrate the experimental data with a statistical inference is advantageous to identify and describe the dynamic changes in a network of genes of interest and ultimately to infer changes in key signalling pathways. In an organ like the mammalian inner ear where there are several different biological processes regulated in a very precise manner, it is more informative to look at these processes as dynamic networks of genes of which key components are transcription factors and their gene expression patterns.

Neurosensory hearing loss is the most common disabling disease worldwide, a large proportion of which involves the loss of hair cells and their associated neurons. Understanding and defining the key gene networks in the development and function of the mammalian inner ear would represent an important step towards defeating deafness. Such advances will potentially lead to new signalling pathways to assist hypothesis generation in regenerative studies and discovery of drug targets.

\section{Acknowledgments}

This work has been supported in part by grants from the Spanish Ministries of Health and Education (PI0-5168 and BFU-200500084), from the Community of Madrid (CAM-PRICITO530), the Royal Society, DIGNA Biotech and Mutua Madrileña. Hortensia Sánchez-Calderón holds a postdoctoral I3P CSIC-Fondo Social Europeo contract. We thank Drs. Guadalupe Camarero, Rafael Cediel, Julio Contreras, Matias HidalgoSánchez, Gervasio Martín-Partido, Dawn Davies and Matthew Holley for their help and useful comments on the manuscript.

\section{References}

ABU-ELMAGD, M., ISHII, Y., CHEUNG, M., REX, M., LE ROUEDEC, D. and SCOTTING, P.J. (2001).cSox3 expression and neurogenesis in the epibranchial placodes. Dev Bio/237: 258-69.

ADAM, J., MYAT, A., LE ROUX, I., EDDISON, M., HENRIQUE, D., ISH-HOROWICZ, D. and LEWIS, J. (1998). Cell fate choices and the expression of Notch, Delta and Serrate homologues in the chick inner ear: parallels with Drosophila senseorgan development. Development 125: 4645-54.

ADAMSKA, M., HERBRAND, H., ADAMSKI, M., KRUGER, M., BRAUN, T. and BOBER, E. (2001). FGFs control the patterning of the inner ear but are not able to induce the full ear program. Mech Dev109: 303-13.

ALSINA, B., ABELLO, G., ULLOA, E., HENRIQUE, D., PUJADES, C. and GIRALDEZ, $F$. (2004). FGF signaling is required for determination of otic neuroblasts in the chick embryo. Dev Bio/267: 119-34.

ALVAREZ, I.S., MARTIN-PARTIDO, G., RODRIGUEZ-GALLARDO, L., GONZALEZ-
RAMOS, C. and NAVASCUES, J. (1989). Cell proliferation during early development of the chick embryo otic anlage: quantitative comparison of migratory and nonmigratory regions of the otic epithelium. J Comp Neuro/290: 278-88.

ALVAREZ, Y., ALONSO, M.T., VENDRELL, V., ZELARAYAN, L.C., CHAMERO, P., THEIL, T., BOSL, M.R., KATO, S., MACONOCHIE, M., RIETHMACHER, D. et al. (2003). Requirements for FGF3 and FGF10 during inner ear formation. Development 130: 6329-38.

ARSENIJEVIC, Y. and WEISS, S. (1998). Insulin-like growth factor-I is a differentiation factor for postmitotic CNS stem cell-derived neuronal precursors: distinct actions from those of brain-derived neurotrophic factor. JNeurosci18: 2118-28.

ARSENIJEVIC, Y., WEISS, S., SCHNEIDER, B. and AEBISCHER, P. (2001). Insulin-like growth factor-I is necessary for neural stem cell proliferation and demonstrates distinct actions of epidermal growth factor and fibroblast growth factor-2. J Neurosci21: 7194-202.

ATAR, O. and AVRAHAM, K.B. (2005). Therapeutics of hearing loss: expectations vs reality. Drug Discov Today 10: 1323-30.

AYASO, E., NOLAN, C.M. and BYRNES, L. (2002). Zebrafish insulin-like growth factor-I receptor: molecular cloning and developmental expression. Mol Cell Endocrinol 191: 137-48.

BARRETT, G.L. (2000). The p75 neurotrophin receptor and neuronal apoptosis. Prog Neurobio/61: 205-29.

BEGBIE, J., BALLIVET, M. and GRAHAM, A. (2002). Early steps in the production of sensory neurons by the neurogenic placodes. Mol Cel/Neurosci21: 502-11.

BENEDETTI, M., LEVI, A. and CHAO, M.V. (1993). Differential expression of nerve growth factor receptors leads to altered binding affinity and neurotrophin responsiveness. Proc Nat/ Acad Sci USA 90: 7859-63.

BERMINGHAM, N.A., HASSAN, B.A., PRICE, S.D., VOLLRATH, M.A., BEN-ARIE, N., EATOCK, R.A., BELLEN, H.J., LYSAKOWSKI, A. and ZOGHBI, H.Y. (1999). Math1: an essential gene for the generation of inner ear hair cells. Science284: 1837-41.

BEVER, M.M., JEAN, Y.Y. and FEKETE, D.M. (2003). Three-dimensional morphology of inner ear development in Xenopus laevis. Dev Dyn 227: 422-30.

BIANCHI, L.M., CONOVER, J.C., FRITZSCH, B., DECHIARA, T., LINDSAY, R.M. and YANCOPOULOS, G.D. (1996). Degeneration of vestibular neurons in late embryogenesis of both heterozygous and homozygous BDNF null mutant mice. Development 122: 1965-73.

BIBEL, M. and BARDE, Y.A. (2000). Neurotrophins: key regulators of cell fate and cell shape in the vertebrate nervous system. Genes Dev 14: 2919-37.

BIBEL, M., HOPPE, E. and BARDE, Y.A. (1999). Biochemical and functional interactions between the neurotrophin receptors trk and p75NTR. Embo J18: 616-22.

BISSONNETTE, J.P. and FEKETE, D.M. (1996). Standard atlas of the gross anatomy of the developing inner ear of the chicken. J Comp Neuro/368: 62030.

BRIGANDE, J.V., KIERNAN, A.E., GAO, X., ITEN, L.E. and FEKETE, D.M. (2000). Molecular genetics of pattern formation in the inner ear: do compartment boundaries play a role? Proc Nat/ Acad Sci USA 97: 11700-6.

BROOKER, R., HOZUMI, K. and LEWIS, J. (2006). Notch ligands with contrasting functions: Jagged1 and Delta1 in the mouse inner ear. Development 133: 127786.

BRUMWELL, C.L., HOSSAIN, W.A., MOREST, D.K. and BERND, P. (2000). Role for basic fibroblast growth factor (FGF-2) in tyrosine kinase (TrkB) expression in the early development and innervation of the auditory receptor: in vitro and in situ studies. Exp Neuro/162: 121-45.

CAMARERO, G., AVENDANO, C., FERNANDEZ-MORENO, C., VILLAR, A., CONTRERAS, J., DE PABLO, F., PICHEL, J.G. and VARELA-NIETO, I. (2001). Delayed inner ear maturation and neuronal loss in postnatal lgf-1-deficient mice. JNeurosci21: 7630-41.

CAMARERO, G., LEON, Y., GOROSPE, I., DE PABLO, F., ALSINA, B., GIRALDEZ, F. and VARELA-NIETO, I. (2003). Insulin-like growth factor 1 is required for survival of transit-amplifying neuroblasts and differentiation of otic neurons. Dev Biol262: 242-53.

CAMARERO, G., VILLAR, M.A., CONTRERAS, J., FERNANDEZ-MORENO, C., PICHEL, J.G., AVENDANO, C. and VARELA-NIETO, I. (2002). Cochlear abnormalities in insulin-like growth factor-1 mouse mutants. Hear Res 170: 211. 
CARNICERO, E., ZELARAYAN, L.C., RUTTIGER, L., KNIPPER, M., ALVAREZ, Y., ALONSO, M.T. and SCHIMMANG, T. (2004). Differential roles of fibroblast growth factor-2 during development and maintenance of auditory sensory epithelia. JNeurosci Res 77: 787-97.

CASACCIA-BONNEFIL, P., GU, C. and CHAO, M.V. (1999). Neurotrophins in cell survival/death decisions. Adv Exp Med Bio/468: 275-82.

CEDIEL, R., RIQUELME, R., CONTRERAS, J., DIAZ, A. and VARELA-NIETO, I. (2006). Sensorineural hearing loss in insulin-like growth factor I-null mice: a new model of human deafness. Eur JNeurosci23: 587-90.

CHAE, J.H., STEIN, G.H. and LEE, J.E. (2004). NeuroD: the predicted and the surprising. $\mathrm{Mol} \mathrm{Ce} / \mathrm{s}$ 18: 271-88.

CHAO, M.V. and BOTHWELL, M. (2002). Neurotrophins: to cleave or not to cleave. Neuron 33: 9-12.

CHAPMAN, S.C., CAI, Q., BLEYL, S.B. and SCHOENWOLF, G.C. (2006). Restricted expression of Fgf16 within the developing chick inner ear. Dev Dyn235: 2276-81.

COLE, L.K., LE ROUX, I., NUNES, F., LAUFER, E., LEWIS, J. and WU, D.K. (2000). Sensory organ generation in the chicken inner ear: contributions of bone morphogenetic protein 4, serrate1 and lunatic fringe. J Comp Neuro/424: 50920.

COLVIN, J.S., FELDMAN, B., NADEAU, J.H., GOLDFARB, M. and ORNITZ, D.M. (1999). Genomic organization and embryonic expression of the mouse fibroblast growth factor 9 gene. Dev Dyn 216: 72-88.

D'AMICO-MARTEL, A. and NODEN, D.M. (1983). Contributions of placodal and neural crest cells to avian cranial peripheral ganglia. Am J Anat 166: 445-68.

DAI, C.F., STEYGER, P.S., WANG, Z.M., VASS, Z. and NUTTALL, A.L. (2004). Expression of Trk A receptors in the mammalian inner ear. Hear Res 187: 1-11.

DAVIES, D. (2007). Temporal and spatial regulation of alpha6 integrin expression during the development of the cochlear-vestibular ganglion. J Comp Neuro/ 502:673-82.

DE SILVA, M.G., HILDEBRAND, M.S., CHRISTOPOULOS, H., NEWMAN, M.R., BELL, K., RITCHIE, M., SMYTH, G.K. and DAHL, H.H. (2006). Gene expression changes during step-wise differentiation of embryonic stem cells along the inner ear hair cell pathway. Acta Otolaryngo/126: 1148-57.

DOETSCH, F. (2003). A niche for adult neural stem cells. Curr Opin Genet Dev13: 543-50.

EDDISON, M., LE ROUX, I. and LEWIS, J. (2000). Notch signaling in the development of the inner ear: lessons from Drosophila. Proc Natl Acad Sci USA 97: 11692-9.

FARINAS, I., JONES, K.R., TESSAROLLO, L., VIGERS, A.J., HUANG, E., KIRSTEIN, M., DE CAPRONA, D.C., COPPOLA, V., BACKUS, C., REICHARDT, L.F. et al. (2001). Spatial shaping of cochlear innervation by temporally regulated neurotrophin expression. JNeurosci21: 6170-80.

FEKETE, D.M. and WU, D.K. (2002). Revisiting cell fate specification in the inner ear. Curr Opin Neurobio/12: 35-42.

FELDMAN, E.L., SULLIVAN, K.A., KIM, B. and RUSSELL, J.W. (1997). Insulin-like growth factors regulate neuronal differentiation and survival. Neurobio/ Dis 4: 201-14.

FISCHER, S., DRAPER, B.W. and NEUMANN, C.J. (2003). The zebrafish fgf24 mutant identifies an additional level of Fgf signaling involved in vertebrate forelimb initiation. Development 130: 3515-24.

FRADE, J.M. (2000). NRAGE and the cycling side of the neurotrophin receptor p75. Trends Neurosci23: 591-2.

FRAGO, L.M., CAMARERO, G., CANON, S., PANEDA, C., SANZ, C., LEON, Y., GIRALDEZ, F. and VARELA-NIETO, I. (2000). Role of diffusible and transcription factors in inner ear development: implications in regeneration. Histo/ Histopathol 15: 657-66.

FRAGO, L.M., CANON, S., DE LA ROSA, E.J., LEON, Y. and VARELA-NIETO, I. (2003). Programmed cell death in the developing inner ear is balanced by nerve growth factor and insulin-like growth factor I. J Cel/ Sci116: 475-86.

FRAGO, L.M., LEON, Y., DE LA ROSA, E.J., GOMEZ-MUNOZ, A. and VARELANIETO, I. (1998). Nerve growth factor and ceramides modulate cell death in the early developing inner ear. $J$ Cel/ Sci111: 549-56.

FRAGO, L.M., SANCHEZ-CALDERON, H., VARELA-NIETO, I. and LEON, Y. (2006). The ceramide/ceramide-1-phosphate biostat in development. In
Sphingolipids and CellFunction, (ed. ALBI, E.). Publications Manager A.Gayathri, Kerala.

FRIEDMAN, R.A., MAKMURA, L., BIESIADA, E., WANG, X. and KEITHLEY, E.M. (2005). Eya1 acts upstream of Tbx1, Neurogenin 1, NeuroD and the neurotrophins BDNF and NT-3 during inner ear development. Mech Dev122: 625-34.

FRITZSCH, B., BARBACID, M. and SILOS-SANTIAGO, I. (1998). The combined effects of trkB and trkC mutations on the innervation of the inner ear. Int J Dev Neurosci 16: 493-505.

FRITZSCH, B., TESSAROLLO, L., COPPOLA, E. and REICHARDT, L.F. (2004). Neurotrophins in the ear: their roles in sensory neuron survival and fiber guidance. Prog Brain Res 146: 265-78.

GONG, T.W., KAROLYI, I.J., MACDONALD, J., BEYER, L., RAPHAEL, Y., KOHRMAN, D.C., CAMPER, S.A. and LOMAX, M.I. (2006). Age-related changes in cochlear gene expression in normal and shaker 2 mice. $J$ Assoc Res Otolaryngol 7: 317-28.

GU, C., CASACCIA-BONNEFIL, P., SRINIVASAN, A. and CHAO, M.V. (1999). Oligodendrocyte apoptosis mediated by caspase activation. J Neurosci 19: 3043-9.

HANS, S., CHRISTISON, J., LIU, D. and WESTERFIELD, M. (2007). Fgf-dependent otic induction requires competence provided by Foxi1 and DIx3b. BMCDev Biol7: 5.

HARRINGTON, A.W., KIM, J.Y. and YOON, S.O. (2002). Activation of Rac GTPase by $\mathrm{p} 75$ is necessary for c-jun $\mathrm{N}$-terminal kinase-mediated apoptosis. JNeurosci 22: 156-66.

HEIN, A.M., RICHARDSON, S., CAUSTON, H.C., AMBLER, G.K. and GREEN, P.J. (2005). BGX: a fully Bayesian integrated approach to the analysis of Affymetrix GeneChip data. Biostatistics 6: 349-73.

HEMOND, S.G. and MOREST, D.K. (1991). Ganglion formation from the otic placode and the otic crest in the chick embryo: mitosis, migration and the basal lamina. Anat Embryol (Berl) 184: 1-13.

HERTZANO, R., MONTCOUQUIOL,M., RASHI-ELKELES, S., ELKON, R., YUCEL, R., FRANKEL, W.N., RECHAVI, G., MOROY, T., FRIEDMAN, T.B., KELLEY, M.W. and AVRAHAM, K.B. (2004). Transcription profiling of inner ears from Pou4f3(ddl/ddl) identifies Gfi1 as a target of the Pou4f3 deafness gene. Hum Mol Genet. 13: 2143-53.

HIDALGO-SANCHEZ, M., ALVARADO-MALLART, R. and ALVAREZ, I.S. (2000). Pax2, Otx2, Gbx2 and Fgf8 expression in early otic vesicle development. Mech Dev 95: 225-9.

HIRATA, H., HIBASAMI, H., YOSHIDA, T., OGAWA, M., MATSUMOTO, M., MORITA, A. and UCHIDA, A. (2001). Nerve growth factor signaling of p75 induces differentiation and ceramide-mediated apoptosis in Schwann cells cultured from degenerating nerves. Glia 36: 245-58.

HOBERT, O. and WESTPHAL, H. (2000). Functions of LIM-homeobox genes. Trends Genet 16: 75-83.

HOLLEY, M.C. (2005). Keynote review: The auditory system, hearing loss and potential targets for drug development. Drug Discov Today 10: 1269-82.

HOLLEY, M.C., KNEEBONE, A. and MILO, M. (2007). Information for gene networks in inner ear development: A study centered on the transcription factor gata2. Hear Res. 227: 32-40.

HOSSAIN, W.A., BRUMWELL, C.L. and MOREST, D.K. (2002). Sequential interactions of fibroblast growth factor-2, brain-derived neurotrophic factor, neurotrophin-3 and their receptors define critical periods in the development of cochlear ganglion cells. Exp Neuro/175: 138-51.

HOSSAIN, W.A. and MOREST, D.K. (2000). Fibroblast growth factors (FGF-1, FGF-2) promote migration and neurite growth of mouse cochlear ganglion cells in vitro: immunohistochemistry and antibody perturbation. JNeurosci Res 62 : 40-55.

HOSSAIN, W.A., ZHOU, X., RUTLEDGE, A., BAIER, C. and MOREST, D.K. (1996). Basic fibroblast growth factor affects neuronal migration and differentiation in normotypic cell cultures from the cochleovestibular ganglion of the chick embryo. Exp Neuro/138: 121-43.

HU, Z. and ULFENDAHL, M. (2006). Cell replacement therapy in the inner ear. Stem Cells Dev 15: 449-59.

HU, Z., WEI, D., JOHANSSON, C.B., HOLMSTROM, N., DUAN, M., FRISEN, J. and ULFENDAHL, M. (2005). Survival and neural differentiation of adult neural stem cells transplanted into the mature inner ear. Exp Cell Res 302: 40-7. 
HUANG, E.J., LIU, W., FRITZSCH, B., BIANCHI, L.M., REICHARDT, L.F. and XIANG, M. (2001). Brn3a is a transcriptional regulator of soma size, target field innervation and axon pathfinding of inner ear sensory neurons. Development 128: 2421-32.

HUANG, E.J. and REICHARDT, L.F. (2001). Neurotrophins: roles in neuronal development and function. Annu Rev Neurosci24: 677-736.

IRIZARRY, R.A., BOLSTAD, B.M., COLLIN, F., COPE, L.M., HOBBS, B. and SPEED, T.P. (2003). Summaries of Affymetrix GeneChip probe level data. Nucleic Acids Res 31: e15.

KAGEYAMA, R., OHTSUKA, T., HATAKEYAMA, J. and OHSAWA, R. (2005). Roles of bHLH genes in neural stem cell differentiation. Exp Cel/ Res 306: 3438.

KALLURI, H.S., VEMUGANTI, R. and DEMPSEY, R.J. (2007). Mechanism of insulin-like growth factor I-mediated proliferation of adult neural progenitor cells: role of Akt. Eur J Neurosci25: 1041-1048.

KARIS, A., PATA, I., VAN DOORNINCK, J.H., GROSVELD, F., DE ZEEUW, C.I. DE CAPRONA, D. and FRITZSCH, B. (2001). Transcription factor GATA-3 alters pathway selection of olivocochlear neurons and affects morphogenesis of the ear. J Comp Neuro/429: 615-30.

$\mathrm{KATOH}, \mathrm{Y}$. and KATOH, M. (2005). Comparative genomics on FGF7, FGF10, FGF22 orthologs and identification of fgf25. Int J Mol Med 16: 767-70.

KIM, W.Y., FRITZSCH, B., SERLS, A., BAKEL, L.A., HUANG, E.J., REICHARDT, L.F., BARTH, D.S. and LEE, J.E. (2001). NeuroD-null mice are deaf due to a severe loss of the inner ear sensory neurons during development. Development 128: 417-26.

KIRKEGAARD, M., MURAI, N., RISLING, M., SUNESON, A., JARLEBARK, L. and ULFENDAHL, M. (2006). Differential gene expression in the rat cochlea after exposure to impulse noise. Neuroscience 142: 425-35.

LADHER, R.K., ANAKWE, K.U., GURNEY, A.L., SCHOENWOLF, G.C. and FRANCIS-WEST, P.H. (2000). Identification of synergistic signals initiating inner ear development. Science 290: 1965-7.

LADHER, R.K., WRIGHT, T.J., MOON, A.M., MANSOUR, S.L. and SCHOENWOLF, G.C. (2005). FGF8 initiates inner ear induction in chick and mouse. Genes Dev 19: 603-13.

LANFORD, P.J., LAN, Y., JIANG, R., LINDSELL, C., WEINMASTER, G., GRIDLEY, T. and KELLEY, M.W. (1999). Notch signalling pathway mediates hair cell development in mammalian cochlea. Nat Genet 21: 289-92.

LANFORD, P.J., SHAILAM, R., NORTON, C.R., GRIDLEY, T. and KELLEY, M.W. (2000). Expression of Math1 and HES5 in the cochleae of wildtype and Jag2 mutant mice. J Assoc Res Otolaryngol1: 161-71.

LANG, H. and FEKETE, D.M. (2001). Lineage analysis in the chicken inner ear shows differences in clonal dispersion for epithelial, neuronal and mesenchymal cells. Dev Bio/234: 120-37.

LAWOKO-KERALI, G., RIVOLTA, M.N. and HOLLEY, M. (2002). Expression of the transcription factors GATA3 and Pax2 during development of the mammalian inner ear. J Comp Neuro/442: 378-91.

LAWOKO-KERALI, G., RIVOLTA, M.N., LAWLOR, P., CACCIABUE-RIVOLTA, D.I., LANGTON-HEWER, C., VAN DOORNINCK, J.H. and HOLLEY, M.C (2004). GATA3 and NeuroD distinguish auditory and vestibular neurons during development of the mammalian inner ear. Mech Dev 121: 287-99.

LEE, R., KERMANI, P., TENG, K.K. and HEMPSTEAD, B.L. (2001). Regulation of cell survival by secreted proneurotrophins. Science 294: 1945-8.

LEGER, S. and BRAND, M. (2002). Fgf8 and Fgf3 are required for zebrafish ear placode induction, maintenance and inner ear patterning. Mech Dev119: 91108.

LEON, Y., SANCHEZ-GALIANO, S. and GOROSPE, I. (2004). Programmed cell death in the development of the vertebrate inner ear. Apoptosis 9: 255-64.

LEON, Y., SANZ, C. GIRALDEZ, F. and VARELA-NIETO, I. (1998). Induction of cell growth by insulin and insulin-like growth factor-I is associated with Jun expression in the otic vesicle. J Comp Neuro/398: 323-32.

LEON, Y., VAZQUEZ. E., SANZ, C. VEGA, J.A., MATO, J.M., GIRALDEZ, F., REPRESA, J. and VARELA-NIETO, I. (1995). Insulin-like growth factor-I regulates cell proliferation in the developing inner ear, activating glycosylphosphatidylinositol hydrolysis and Fos expression. Endocrinology 136: 3494503.

LEROITH, D., WERNER, H., BEITNER-JOHNSON, D. and ROBERTS, C.T., JR.
(1995). Molecular and cellular aspects of the insulin-like growth factor I receptor. Endocr Rev 16: 143-63.

LI, H., CORRALES, C.E., EDGE, A. and HELLER, S. (2004a). Stem cells as therapy for hearing loss. Trends Mol Med 10: 309-15.

LI, H., LIU, H. and HELLER, S. (2003a). Pluripotent stem cells from the adult mouse inner ear. Nat Med 9: 1293-9.

LI, H., LIU, H., SAGE, C., HUANG, M., CHEN, Z.Y. and HELLER, S. (2004b). Islet1 expression in the developing chicken inner ear. J Comp Neuro/477: 1-10.

LI, H., ROBLIN, G., LIU, H. and HELLER, S. (2003b). Generation of hair cells by stepwise differentiation of embryonic stem cells. Proc Nat/ Acad Sci USA 100: 13495-500.

LILLEVALI, K., HAUGAS, M., MATILAINEN, T., PUSSINEN, C., KARIS, A. and SALMINEN, M. (2006). Gata3 is required for early morphogenesis and Fgf10 expression during otic development. Mech Dev 123: 415-29.

LILLEVALI, K., MATILAINEN, T., KARIS, A. and SALMINEN, M. (2004). Partially overlapping expression of Gata2 and Gata3 during inner ear development. Dev Dyn 231: 775-81.

LIU, M., PEREIRA, F.A., PRICE, S.D., CHU, M.J., SHOPE, C., HIMES, D., EATOCK, R.A., BROWNELL, W.E., LYSAKOWSKI, A. and TSAI, M.J. (2000) Essential role of BETA2/NeuroD1 in development of the vestibular and auditory systems. Genes Dev 14: 2839-54

LIU, X., MILO, M., LAWRENCE, N.D. and RATTRAY, M. (2005). A tractable probabilistic model for Affymetrix probe-level analysis across multiple chips. Bioinformatics 21: 3637-44.

LOCKHART, D.J., DONG, H., BYRNE, M.C., FOLLETTIE, M.T., GALLO, M.V., CHEE, M.S., MITTMANN, M., WANG, C., KOBAYASHI, M., HORTON, H. et al. (1996). Expression monitoring by hybridization to high-density oligonucleotide arrays. Nat Biotechno/14: 1675-80.

MA, Q., ANDERSON, D.J. and FRITZSCH, B. (2000). Neurogenin 1 null mutant ears develop fewer, morphologically normal hair cells in smaller sensory epithelia devoid of innervation. J Assoc Res Otolaryngo/1: 129-43.

MA, Q., CHEN, Z., DEL BARCO BARRANTES, I., DE LA POMPA, J.L. and ANDERSON, D.J. (1998). neurogenin1 is essential for the determination of neuronal precursors for proximal cranial sensory ganglia. Neuron 20: 469-82

MAHMOOD, R., KIEFER, P., GUTHRIE, S., DICKSON, C. and MASON, I. (1995) Multiple roles for FGF-3 during cranial neural development in the chicken Development 121: 1399-410.

MALGRANGE, B., RIGO, J.M., COUCKE, P., THIRY, M., HANS, G., NGUYEN, L. VAN DE WATER, T.R., MOONEN, G. and LEFEBVRE, P.P. (2002). Identification of factors that maintain mammalian outer hair cells in adult organ of Corti explants. Hear Res 170: 48-58.

MANSOUR, S.L., GODDARD, J.M. and CAPECCHI, M.R. (1993). Mice homozygous for a targeted disruption of the proto-oncogene int-2 have developmental defects in the tail and inner ear. Development 117: 13-28.

MEMBERG, S.P. and HALL, A.K. (1995). Dividing neuron precursors express neuron-specific tubulin. JNeurobio/27: 26-43.

MERKLE, F.T. and ALVAREZ-BUYLLA, A. (2006). Neural stem cells in mammalian development. Curr Opin Cel/ Biol 18: 704-9.

MILO, M., FAZELI, A., NIRANJAN, M. and LAWRENCE, N.D. (2003). A probabilistic model for the extraction of expression levels from oligonucleotide arrays Biochem Soc Trans 31: 1510-2.

MOLLER, A.R. (2006), Hearing: anatomy physiology and disorders of the auditory system, Elsevier, $2^{\text {nd }}$ ed.; ISBN: 978-0-12-372519-6.

NICHOLL, A.J., KNEEBONE, A., DAVIES, D., CACCIABUE-RIVOLTA, D.I., RIVOLTA, M.N., COFFEY, P. and HOLLEY, M.C. (2005). Differentiation of an auditory neuronal cell line suitable for cell transplantation. Eur J Neurosci22: 343-53.

NYKJAER, A., LEE, R., TENG, K.K., JANSEN, P., MADSEN, P., NIELSEN, M.S. JACOBSEN, C., KLIEMANNEL, M., SCHWARZ, E., WILLNOW, T.E., HEMPSTEAD, B.L. and PETERSEN, C.M. (2004). Sortilin is essential for proNGF-induced neuronal cell death. Nature 427: 843-8.

OKANO, T., NAKAGAWA, T., ENDO, T., KIM, T.S., KITA, T., TAMURA, T. MATSUMOTO, M., OHNO, T., SAKAMOTO, T., IGUCHI, F. et al. (2005). Engraftment of embryonic stem cell-derived neurons into the cochlear modiolus. Neuroreport 16: 1919-22.

OTAEGI, G., YUSTA-BOYO, M.J., VERGANO-VERA, E., MENDEZ-GOMEZ, H.R., 
CARRERA, A.C., ABAD, J.L., GONZALEZ, M., DE LA ROSA, E.J., VICARIOABEJON, C. and DE PABLO, F. (2006). Modulation of the PI 3-kinase-Akt signalling pathway by IGF-I and PTEN regulates the differentiation of neural stem/precursor cells. J Cell Sci119: 2739-48.

OHUCHI, H., YASUE, A., ONO, K., SASAOKA, S., TOMONARI, S., TAKAGI, A., ITAKURA, M., MORIYAMA, K., NOJI, S. and NOHNO, T. (2005). Identification of cis-element regulating expression of the mouse Fgf10 gene during inner ear development. Dev Dyn 233:177-187.

PAULEY, S., WRIGHT, T.J., PIRVOLA, U., ORNITZ, D., BEISEL, K. and FRITZSCH, B. (2003). Expression and function of FGF10 in mammalian inner ear development. Dev Dyn 227: 203-15.

PHILLIPS, B.T., BOLDING, K. and RILEY, B.B. (2001). Zebrafish fgf3 and fgf8 encode redundant functions required for otic placode induction. Dev Bio/235: 351-65.

PIRVOLA, U., ARUMAE, U., MOSHNYAKOV, M., PALGI, J., SAARMA, M. and YLIKOSKI, J. (1994). Coordinated expression and function of neurotrophins and their receptors in the rat inner ear during target innervation. Hear Res 75: 131-44.

PIRVOLA, U., SPENCER-DENE, B., XING-QUN, L., KETTUNEN, P., THESLEFF, I., FRITZSCH, B., DICKSON, C. and YLIKOSKI, J. (2000). FGF/FGFR-2(IIIb) signaling is essential for inner ear morphogenesis. J Neurosci 20: 6125-34.

PIRVOLA, U. and YLIKOSKI, J. (2003). Neurotrophic factors during inner ear development. Curr Top Dev Bio/57: 207-23.

PIRVOLA, U., YLIKOSKI, J., PALGI, J., LEHTONEN, E., ARUMAE, U. and SAARMA, M. (1992). Brain-derived neurotrophic factor and neurotrophin 3 mRNAs in the peripheral target fields of developing inner ear ganglia. Proc Nat/Acad Sci USA 89: 9915-9.

PIRVOLA, U., YLIKOSKI, J., TROKOVIC, R., HEBERT, J.M., MCCONNELL, S.K. and PARTANEN, J. (2002). FGFR1 is required for the development of the auditory sensory epithelium. Neuron 35: 671-80.

POWERS, C.J., MCLESKEY, S.W. and WELLSTEIN, A. (2000). Fibroblast growth factors, their receptors and signaling. Endocr Relat Cancer 7: 165-97.

RADDE-GALLWITZ, K., PAN, L., GAN, L., LIN, X., SEGIL, N. and CHEN, P. (2004). Expression of Islet 1 marks the sensory and neuronal lineages in the mammalian inner ear. J Comp Neurol. 477:412-21.

RAFT, S., NOWOTSCHIN, S., LIAO, J. and MORROW, B.E. (2004). Suppression of neural fate and control of inner ear morphogenesis by Tbx1. Development 131: 1801-12.

RAPHAEL, Y. and ALTSCHULER, R.A. (2003). Structure and innervation of the cochlea. Brain Res Bul/60: 397-422.

RASK-ANDERSEN, H., BOSTROM, M., GERDIN, B., KINNEFORS, A., NYBERG, G., ENGSTRAND, T., MILLER, J.M. and LINDHOLM, D. (2005). Regeneration of human auditory nerve. In vitro/in video demonstration of neural progenitor cells in adult human and guinea pig spiral ganglion. Hear Res 203: 180-91.

RIVOLTA, M.N., HALSALL, A., JOHNSON, C.M., TONES, M.A. and HOLLEY, M.C. (2002). Transcript profiling of functionally related groups of genes during conditional differentiation of a mammalian cochlear hair cell line. Genome Res 12: $1091-9$

RIVOLTA, M.N. and HOLLEY, M.C. (1998). GATA3 is downregulated during hair cell differentiation in the mouse cochlea. J Neurocyto/27: 637-47.

ROEHM, P.C. and HANSEN, M.R. (2005). Strategies to preserve or regenerate spiral ganglion neurons. Curr Opin Otolaryngol Head Neck Surg 13: 294-300.

RUSSO, V.C., GLUCKMAN, P.D., FELDMAN, E.L. and WERTHER, G.A. (2005). The insulin-like growth factor system and its pleiotropic functions in brain. Endocr Rev 26: 916-43.

SANCHEZ-CALDERON, H., FRANCISCO-MORCILLO, J., MARTIN-PARTIDO, G. and HIDALGO-SANCHEZ, M. (2007). Fgf19 expression patterns in the developing chick inner ear. Gene Expr Patterns 7: 30-8.

SANCHEZ-CALDERON, H., MARTIN-PARTIDO, G. and HIDALGO-SANCHEZ, M. (2004). Otx2, Gbx2 and Fgf8 expression patterns in the chick developing inner ear and their possible roles in otic specification and early innervation. Gene Expr Patterns 4: 659-69.

SANZ, C., LEON, Y., CANON, S., ALVAREZ, L., GIRALDEZ, F. and VARELANIETO, I. (1999a). Pattern of expression of the jun family of transcription factors during the early development of the inner ear: implications in apoptosis. $J$ Cell Sci112: 3967-74.
SANZ, C., LEON, Y., TROPPMAIR, J., RAPP, U.R. and VARELA-NIETO, I. (1999b). Strict regulation of c-Raf kinase levels is required for early organogenesis of the vertebrate inner ear. Oncogene 18: 429-37.

SATO, T., DOI, K., TANIGUCHI, M., YAMASHITA, T., KUBO, T. and TOHYAMA, $M$. (2006). Progressive hearing loss in mice carrying a mutation in the p75 gene. Brain Res 1091: 224-34.

SCHECTERSON, L.C. and BOTHWELL, M. (1994). Neurotrophin and neurotrophin receptor mRNA expression in developing inner ear. Hear Res 73: 92-100.

SCHENA, M., SHALON, D., DAVIS, R.W. and BROWN, P.O. (1995). Quantitative monitoring of gene expression patterns with a complementary DNA microarray. Science 270: 467-70.

SCHLUETER, P.J., PENG, G., WESTERFIELD, M. and DUAN, C. (2007). Insulinlike growth factor signaling regulates zebrafish embryonic growth and development by promoting cell survival and cell cycle progression. Cel/Death Differ. 14: 1095-105.

SLIWINSKA-KOWALSKA, M., RZADZINSKA, A., RAJKOWSKA, E. and MALCZYK, M. (2005). Expression of bFGF and NGF and their receptors in chick's auditory organ following overexposure to noise. Hear Res 210: 93-103.

SUGIURA, M., KONO, K., LIU, H., SHIMIZUGAWA, T., MINEKURA, H., SPIEGEL, S. and KOHAMA, T. (2002). Ceramide kinase, a novel lipid kinase. Molecula cloning and functional characterization. J Biol Chem 277: 23294-300.

TAN, J. and SHEPHERD, R.K. (2006). Aminoglycoside-induced degeneration of adult spiral ganglion neurons involves differential modulation of tyrosine kinase $B$ and p75 neurotrophin receptor signaling. Am J Patho/169: 528-43.

TANNAHILL, D., ISAACS, H.V., CLOSE, M.J., PETERS, G. and SLACK, J.M. (1992). Developmental expression of the Xenopus int-2 (FGF-3) gene: activation by mesodermal and neural induction. Development 115: 695-702.

TATEYA, I., NAKAGAWA, T., IGUCHI, F., KIM, T.S., ENDO, T., YAMADA, S., KAGEYAMA, R., NAITO, Y. and ITO, J. (2003). Fate of neural stem cells grafted into injured inner ears of mice. Neuroreport 14: 1677-81.

TEKIN, M., HISMI, B.O., FITOZ, S., OZDAG, H., CENGIZ, F.B., SIRMACI, A., ASLAN, I., INCEOGLU, B., YUKSEL-KONUK, E.B., YILMAZ, S.T. et al. (2007). Homozygous mutations in fibroblast growth factor 3 are associated with a new form of syndromic deafness characterized by inner ear agenesis, microtia and microdontia. Am J Hum Genet 80: 338-44.

TROY, C.M., FRIEDMAN, J.E. and FRIEDMAN, W.J. (2002). Mechanisms of p75mediated death of hippocampal neurons. Role of caspases. J Biol Chem 277: 34295-302.

VARELA-NIETO, I., DE LA ROSA, E.J., VALENCIANO, A.I. and LEON, Y. (2003) Cell death in the nervous system: lessons from insulin and insulin-like growth factors. Mol Neurobio/28: 23-50.

VARELA-NIETO, I., MORALES-GARCIA, J.A., VIGIL, P., DIAZ-CASARES, A., GOROSPE, I., SANCHEZ-GALIANO, S., CANON, S., CAMARERO, G. CONTRERAS, J., CEDIEL, R. et al. (2004). Trophic effects of insulin-like growth factor-I (IGF-I) in the inner ear. Hear Res 196: 19-25.

VENDRELL, V., CARNICERO, E., GIRALDEZ, F., ALONSO, M.T. and SCHIMMANG, T. (2000). Induction of inner ear fate by FGF3. Development 127: 2011-9.

VON BARTHELD, C.S., HEUER, J.G. and BOTHWELL, M. (1991). Expression of nerve growth factor (NGF) receptors in the brain and retina of chick embryos: comparison with cholinergic development. J Comp Neuro/310: 103-29.

VON SCHACK, D., CASADEMUNT, E., SCHWEIGREITER, R., MEYER, M., BIBEL, M. and DECHANT, G. (2001). Complete ablation of the neurotrophin receptor p75NTR causes defects both in the nervous and the vascular system. Nat Neurosci 4: 977-8.

WALENKAMP, M.J., KARPERIEN, M., PEREIRA, A.M., HILHORST-HOFSTEE, Y., VAN DOORN, J., CHEN, J.W., MOHAN, S., DENLEY, A., FORBES, B., VAN DUYVENVOORDE, H.A. et al. (2005). Homozygous and heterozygous expression of a novel insulin-like growth factor-I mutation. J Clin Endocrino/ Metab90 2855-64.

WALENKAMP, M.J. and WIT, J.M. (2006). Genetic Disorders in the Growth Hormone - Insulin-Like Growth Factor-I Axis. Horm Res 66: 221-230.

WALLIS, D., HAMBLEN, M., ZHOU, Y., VENKEN, K.J., SCHUMACHER, A., GRIMES, H.L., ZOGHBI, H.Y., ORKIN, S.H. and BELLEN, H.J. (2003). The zinc finger transcription factor Gfi1, implicated in lymphomagenesis, is required for inner ear hair cell differentiation and survival. Development 130: 221-32.

WEI, D., JIN, Z., JARLEBARK, L., SCARFONE, E. and ULFENDAHL, M. (2006). 
Survival, synaptogenesis and regeneration of adult mouse spiral ganglion neurons in vitro. J Neurobio/67: 108-122.

WHITEHEAD, M.C. and MOREST, D.K. (1985). The growth of cochlear fibers and the formation of their synaptic endings in the avian inner ear: a study with the electron microscope. Neuroscience 14: 277-300.

WILKINSON, D.G., BHATT, S. and MCMAHON, A.P. (1989). Expression pattern of the FGF-related proto-oncogene int-2 suggests multiple roles in fetal development. Development 105: 131-6.

WILLIAMS, B.J., BIMONTE-NELSON, H.A. and GRANHOLM-BENTLEY, A.C. (2006). ERK-mediated NGF signaling in the rat septo-hippocampal pathway diminishes with age. Psychopharmacology (Berl) 188: 605-18.

WOODS, K.A., CAMACHO-HUBNER, C., BARTER, D., CLARK, A.J. and SAVAGE, M.O. (1997). Insulin-like growth factor I gene deletion causing intrauterine growth retardation and severe short stature. Acta Paediatr Supp/423: 39-45.

WOODS, K.A., CAMACHO-HUBNER, C., SAVAGE, M.O. and CLARK, A.J. (1996). Intrauterine growth retardation and postnatal growth failure associated with deletion of the insulin-like growth factor I gene. NEng/ J Med 335: 1363-7.

WRIGHT, T.J., LADHER, R., MCWHIRTER, J., MURRE, C., SCHOENWOLF, G.C. and MANSOUR, S.L. (2004). Mouse FGF15 is the ortholog of human and chick FGF19, but is not uniquely required for otic induction. Dev Bio/269: 264-75.

WRIGHT, T.J. and MANSOUR, S.L. (2003). FGF signaling in ear development and innervation. Curr Top Dev Bio/57: 225-59.

WU, D.K. and OH, S.H. (1996). Sensory organ generation in the chick inner ear. $J$ Neurosci 16: 6454-62.

XIANG, M., GAN, L., LI, D., CHEN, Z.Y., ZHOU, L., O'MALLEY, B.W., JR., KLEIN, W. and NATHANS, J. (1997). Essential role of POU-domain factor Brn-3c in auditory and vestibular hair cell development. Proc Nat/Acad Sci USA94: 944550 .
XIANG, M., MAKLAD, A., PIRVOLA, U. and FRITZSCH, B. (2003). Brn3c null mutant mice show long-term, incomplete retention of some afferent inner ear innervation. BMC Neurosci 4:2.

XIE, M.H., HOLCOMB, I., DEUEL, B., DOWD, P., HUANG, A., VAGTS, A., FOSTER, J., LIANG, J., BRUSH, J., GU, Q. et al. (1999). FGF-19, a novel fibroblast growth factor with unique specificity for FGFR4. Cytokine 11: 729-35.

XU, H., VIOLA, A., ZHANG, Z., GERKEN, C.P., LINDSAY-ILLINGWORTH, E.A. and BALDINI, A. (2007). Tbx1 regulates population, proliferation and cell fate determination of otic epithelial cells. Dev Bio/302: 670-82.

YE, P. and D'ERCOLE, A.J. (2006). Insulin-like growth factor actions during development of neural stem cells and progenitors in the central nervous system. $J$ Neurosci Res 83: 1-6.

ZHENG, J.L. and GAO, W.Q. (2000). Overexpression of Math1 induces robust production of extra hair cells in postnatal rat inner ears. Nat Neurosci3: 580-6.

ZHENG, J.L., HELBIG, C. and GAO, W.Q. (1997). Induction of cell proliferation by fibroblast and insulin-like growth factors in pure rat inner ear epithelial cell cultures. J Neurosci 17: 216-26.

ZHENG, J.L., SHOU, J., GUILLEMOT, F., KAGEYAMA, R. and GAO, W.Q. (2000). Hes 1 is a negative regulator of inner ear hair cell differentiation. Development 127: 4551-60.

ZINE, A., AUBERT, A., QIU, J., THERIANOS, S., GUILLEMOT, F., KAGEYAMA, R. and DE RIBAUPIERRE, F. (2001). Hes 1 and Hes5 activities are required for the normal development of the hair cells in the mammalian inner ear. JNeurosci21: 4712-20. 


\section{Related, previously published Int. J. Dev. Biol. articles \\ See our Special Issue Ear Development edited by Fernando Giraldez and Bernd Fritzsch at: http://www.ijdb.ehu.es/web/contents.php?vol=51\&issue=6-7}

Equivalent genetic regulatory networks in different contexts recover contrasting spatial cell patterns that resemble those in Arabidopsis root and leaf epidermis: a dynamic model

Mariana Benítez, Carlos Espinosa-Soto, Pablo Padilla-Longoria, José Díaz and Elena R. Alvarez-Buylla Int. J. Dev. Biol. (2007) 51: 139-155

Expression and regulation of Xenopus CRMP-4 in the developing nervous system Jacob Souopgui, Tiemo J. Klisch, Tomas Pieler and Kristine A. Henningfeld Int. J. Dev. Biol. (2007) 51: 339-343

$\mathrm{XSu}(\mathrm{H}) 2$ is an essential factor for gene expression and morphogenesis of the Xenopus gastrula embryo Motoaki Ito, Tomohisa Katada, Seiji Miyatani and Tsutomu Kinoshita

Int. J. Dev. Biol. (2007) 51: 27-36

Gene network analysis in plant development by genomic technologies

Frank Wellmer and José Luis Riechmann

Int. J. Dev. Biol. (2005) 49: 745-759

Single-cell transcriptional profiles and spatial patterning of the mammalian olfactory epithelium lan Tietjen, Jason Rihel and Catherine G. Dulac

Int. J. Dev. Biol. (2005) 49: 201-207

The chemokine network in cancer - much more than directing cell movement Hagen Kulbe, Neil R. Levinson, Fran Balkwill and Julia L. Wilson

Int. J. Dev. Biol. (2004) 48: 489-496

Insulin-like growth factor (IGF) signalling is required for early dorso-anterior development of the zebrafish embryo

Edward Eivers, Karena Mccarthy, Catherine Glynn, Catherine M. Nolan and Lucy Byrnes

Int. J. Dev. Biol. (2004) 48: 1131-1140

Developmental gene network analysis.

Roger Revilla-i-Domingo and Eric H Davidson

Int. J. Dev. Biol. (2003) 47: 695-703

Adaptive walks in a gene network model of morphogenesis: insights into the Cambrian explosion. Ricard V Solé, Pau Fernández and Stuart A Kauffman

Int. J. Dev. Biol. (2003) 47: 685-693

XMam1, the Xenopus homologue of mastermind, is essential to primary neurogenesis in Xenopus laevis embryos.

Tomohisa Katada and Tsutomu Kinoshita

Int. J. Dev. Biol. (2003) 47: 397-404

Conserved genetic mechanisms for embryonic brain patterning.

Heinrich Reichert

Int. J. Dev. Biol. (2002) 46: 81-87 